\title{
Are Agricultural Markets in the Punjab Technically Efficient?
}

\section{Mahniya Zafar, Naved Hamid ${ }^{* *}$ and Fatima Arshad ${ }^{* * *}$}

\begin{abstract}
We test the technical efficiency, measured by the degree of integration, of agriculture markets for five crops in the Punjab province of Pakistan using daily wholesale market prices from the Agriculture Management Information System (AMIS). We find that potato, onion and mango markets are well integrated both horizontally and vertically, with the speed of price adjustment in most cases (mango is the exception) being very rapid. We also find that kinnow and basmati rice markets are both vertically fairly well integrated. Furthermore, we find that trends in cropping patterns over the period 2000 to 2014 are in line with the changing market demand and government price interventions. The reforms introduced by the Punjab Agriculture Marketing Regulatory Authority (PAMRA) Act 2020, aimed at increasing competition in agriculture markets, have the potential to significantly improve economic efficiency.
\end{abstract}

Keywords: Agricultural prices, market integration, price transmission, market efficiency, agriculture marketing.

JEL Classification: Q110, Q111, Q113 and C110.

\section{Introduction}

Agriculture plays a significant role in economic development not only for ensuring food and nutritional security but is the major source of

\footnotetext{
* Teaching and Research Fellow, Centre for Research in Economics and Business (CREB), Lahore School of Economics, Pakistan. Email: mahniyazafar@gmail.com

${ }^{* *}$ Professor and Director Centre for Research in Economics and Business (CREB), Lahore School of Economics, Pakistan. Email: navedhamid@gmail.com

${ }^{* * *}$ Research Associate, Centre for Economic Research in Pakistan (CERP). Email: afatima.0013@hotmail.com

We would like to thank Dr. Syeda Rabab for her tremendous support and help in understanding, running and interpreting the results of VAR models (or framework). However, it goes without saying, that any errors that remain are entirely the responsibility of the authors.
} 
rural employment and contributes substantially to earnings from exports. While the relative importance of agriculture has been declining in South Asia, it is still considerable. The agriculture sector contributes about 40 percent of total employment in Bangladesh, India and Pakistan, and over 50 percent in Bhutan and Nepal (International Labor Organization, 2018) 1 . Agriculture also accounts for over 20 percent of GDP in Pakistan and Nepal, and about 15 percent in Bangladesh, Bhutan and India (World Development Indicators, 2018)2.

In Pakistan, agricultural sector growth has slowed significantly since 2000, with the slowdown being greater in the crops sub-sector (see Figure 1$)^{3}$. There is no consensus on why the decline in the growth rate has occurred, but factors such as "inequality in farm sizes, limited investment in irrigation systems, the slowing of adoption of new technology and techniques and a weak extension service" have been cited as likely causes (Valdes, 2013).

We suggest that the lack of efficiency of agricultural markets is an additional factor responsible for this slowdown. We know that there are multiple players at each stage of the agricultural marketing chain, that the legal and regulatory framework of agricultural markets in the Punjab (and the rest of the country) is archaic (Ahsan 2018) and that marketing margins are high ${ }^{4}$. It is our view that inefficient agricultural markets could be eroding the incentives for the producers to invest in productivity enhancing inputs and technologies. We posit that market efficiency can be divided into two components, i.e. economic efficiency and technical efficiency.

An economically efficient agricultural marketing system, defined as a system where competition throughout the marketing chain, results in total marketing costs of agricultural products being minimized and profits earned by each of the players in the marketing chain being no more than normal; and a technically efficient agricultural market being defined as one where the various agricultural markets in the region are well integrated.

\footnotetext{
${ }^{1}$ https://data.worldbank.org/indicator/SL.AGR.EMPL.ZS

2 http://wdi.worldbank.org/table/4.2

${ }^{3}$ Agricultural growth has been declining since the 1990s, but it was still fairly healthy until 2000.

${ }^{4}$ According to the World Bank, prior to the recent [in 2020] reforms "Farmers' produce used to pass through seven or eight different hands before reaching the consumer. Consequently, market margins were high, but producers were left with little" (https://blogs.worldbank.org/ endpovertyinsouthasia/modernizing-punjabs-farming-benefit-farmers-and-consumers)
} 
In this article, we will focus on testing for technical efficiency of the agricultural marketing system because, unfortunately, due to the lack of data on farm gate prices and margins at different stages of the marketing chain it is difficult for us to say much about its economic efficiency. ${ }^{5}$

Figure 1: Historical Growth Rates for Pakistan's Agriculture and Crops

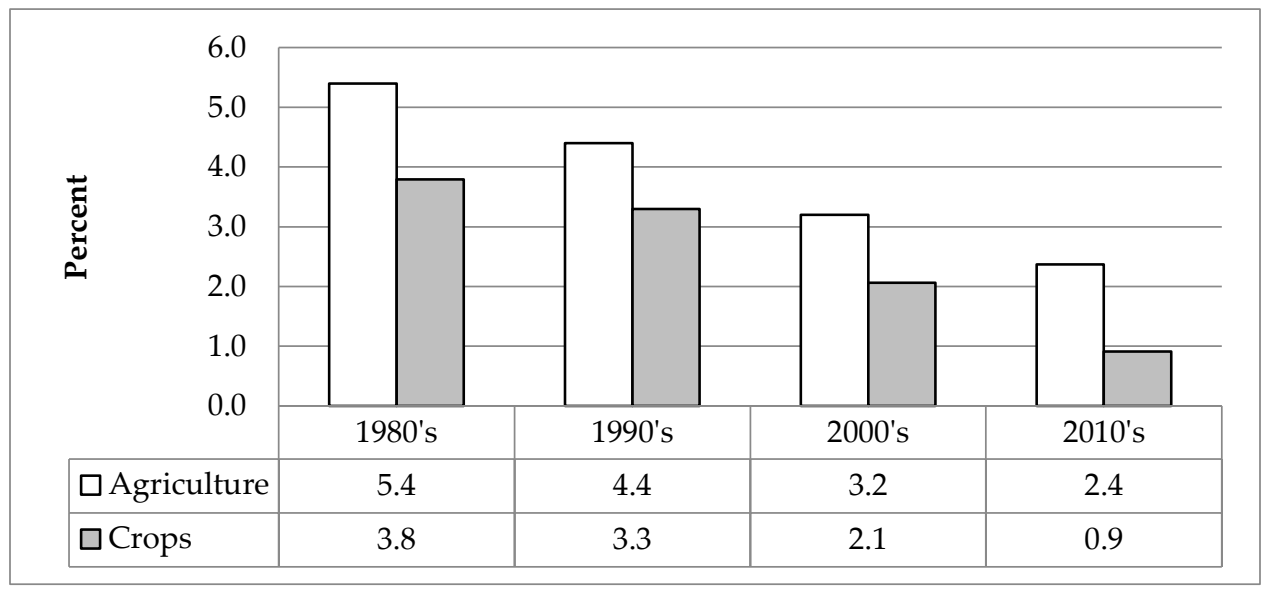

Source: Pakistan Economic Survey (1980-2016).

Market integration has been defined as the tradability or contestability between markets (Barret and Li, 2002). It can be interpreted as the extent to which price shocks are transmitted between spatially separate markets (Goodwin, 2006) and can be measured in terms of strength and speed of price transmission between markets across various regions of a country (Beag and Singla, 2014). Market integration is undoubtedly important because until agricultural markets are integrated, producers and consumers will not realize their potential gains (Reddy, 2012) and the degree to which consumers and producers can benefit depends on how domestic markets are integrated with world markets and how the regional markets are integrated with each (Varela et al., 2012).

\footnotetext{
${ }^{5}$ The economic efficiency of agricultural markets in the Punjab is expected to improve following the approval in March by the Punjab Assembly of the PAMRA Act-short for Punjab Agriculture Marketing Regulatory Authority Act 2020. The new law establishes a more transparent legal regime to market agricultural produce to help safeguard the free flow of crops and stimulate food supply (https://blogs.worldbank.org/endpovertyinsouthasia/modernizing-punjabs-farming-benefitfarmers-and-consumers).
} 
The concept of market integration is often used as a measure of market efficiency; however, in our view it is more appropriate to think of it as a measure of the 'technical efficiency' of a market; this is how we use it in this paper, with technical efficiency of the market for various crops being evaluated in terms of transmission of price information among the producer markets and between producer and consumer markets. Our research not only adds to our understanding of the working of the agriculture markets in Pakistan, but it also contributes to the overall literature on agricultural markets because our analysis of market integration is based on a unique data set that has daily price information, in contrast to most of the existing research on integration in agricultural product markets, which is based on analysis of monthly price data ${ }^{6}$.

We selected five crops for analysis, namely, potato, onion, mango, kinnow and basmati rice. To test for strength and speed of price transmission between agricultural markets, we use vector auto regressive (VAR) models. It is seen that potato, onion and mango markets are well integrated both horizontally and vertically, with the speed of price adjustment in most cases (mango is the exception) being very rapid. Therefore, we can say that these three markets are technically efficient. As far as kinnow and basmati rice markets are concerned, both are vertically fairly well integrated but we are unable to satisfactorily measure the extent of horizontal integration due to lack of data.

In Section 2, we review the literature on market integration from the perspective of methodologies used and the extent of market integration estimated for different crops in other countries. Section 3 provides a description of the data and research methodology and in Section 4 we discuss the results. Section 5 provides a reality check on the impact of efficient agricultural markets and Section 6 concludes.

\section{Review of Literature}

There is considerable literature on market integration and price transmission. Markets are said to be integrated when a price increase or decrease (shock) is transmitted to vertically or between spatially connected

\footnotetext{
${ }^{6}$ Kinnucan and Forker, 1987; Goletti, Ahmed \&Farid, 1995; Parsley and Wei, 1996; Dawson and Dey, 2002; Kaabia et al., 2002; Rapsomanikis et al., 2003; Goodwin and Holt, 2006; Weber and Lee, 2006; Trung et al., 2007, Baulch 2008; Bakucs et al., 2013.
} 
distinct markets (Jena, 2016), whereas price transmission is the extent to which market shocks are transmitted up and down in the marketing chain (Goodwin, 2006). The degree to which a price shock in one market affects a price in another market can indicate whether efficient arbitrage exists between the two markets (Rapsomanikis et al., 2004).

Different authors have explained price transmission through two ways: 1) on the basis of the concept of the Law of One Price (Baffes, 1991; Yang et al., 2000) and 2) in terms of market integration, an approach that has been far more commonly used ${ }^{7}$. The Law of One Price (LOP) states, "In markets linked by trade and arbitrage, homogeneous goods will have a unique price, when expressed in the same currency, net of transaction costs" (Ibid, p. 83). Under market integration a further division that can be made is the extent of spatial and vertical market integration. "Spatial market integration refers to co-movement of prices, and more generally, to the smooth transmission of price signals and information across spatially separated markets" (Goletti et al., 1995). It implies that the difference between prices in different marketplaces will never exceed transaction costs (Listorti \& Esposti, 2012). Vertical price transmission means movement of price along the supply chain from the consumer to the producer level (Rapsomanikis et al., 2004).

Studies on spatial market integration show how regional markets are linked using data on agricultural products. In the case of markets for cereals in developing countries, generally the evidence is of strong or perfect spatial integration (Dawson and Dey, 2002 for Bangladesh; Ghosh, 2003, Makama et al., 2016 for India; Zahid et al., 2007 for Pakistan; Baulch, 2008 for Vietnam); but in a few cases only weak evidence was found (Trung et al., 2007 for Vietnam). There were only a few studies on vegetables or fruit markets, but in those as well there is evidence of strong spatial integration (Ramadas et al, 2014, KC and Rajalaxmi, 2019, bothfor India).

Speaking of vertical price transmission, studies on vegetable markets found stable long run relationship between prices either between producer

\footnotetext{
${ }^{7}$ Ravallion, 1986; Palaskas and Harriss 1993; Gardner \& Brooks, 1994; Baulch 1997; Dawson \&Dey, 2002; Kaabia et al., 2002; Rapsomanikis et al., 2003; Ghosh, 2003; Weber \& Lee, 2006; Trung et al., 2007; Zahid et al., 2007; Baulch, 2008; Bakus, 2013; Ramadas et al., 2014; Paul et al., 2015; Tadesse, 2016; Kharin et al., 2017; Usman \& Haile, 2017; KC \&Rajalaxmi, 2019; Ozturk, 2020.
} 
and consumer markets (Tadesse, 2016 for Ethiopia) or between export and domestic markets (Paul et al., 2015, for India). A few studies on cereals and grains market found weak evidence for vertical price transmission in the long run among domestic markets and domestic and international markets (Usman and Haile, 2017 for Ethiopia; Ozturk, 2020, for Turkey). A metaanalysis of European agriculture found that vertical price transmission is asymmetric in both the long and shortrun (Bakus, 2013). Studies on meat and dairy markets found vertical integration between the farm, wholesale and retail markets in the long run and full transmission of all supply and demand shocks to prices prevalent in the system (Kaabia et al., 2002, for Spain; Kharin et al., 2017, for Slovakia). The studies explaining price transmission base their results on monthly price data.

Studies on a variety of goods, both agriculture and non-agriculture, using quarterly data of prices, found that vertical price convergence takes place faster for tradable goods than for non-tradable goods (Yazgan and Yilmazkuday, 2011; Parsley and Wei, 1996, all for USA).

Studies on price transmission and market integration use numerous time series techniques. Techniques such as vector auto regressive and error correction models have become the standard instruments for investigating market relationships (Jena, 2016). While vector auto regressive (VAR) models check for size and speed of price adjustment among markets (Rapsomanikis et al., 2004), vector error correction (VECM) models check for long-run relationships mainly through the estimation of cointegration ${ }^{8}$ among price series (Maitra, 2019). Both methods are used commonly in literature: Dawson and Dey, 2002, VAR; Ramadas et al., 2004, VAR; Baulch, 2008; Zahid et al., 2007; Trung et al., 2007; Tadesse, 2016; Usman and Haile, 2017; KC and Rajalaxmi, 2019; Ozturk, 2020, all use VECM.

According to Rapsomanikis et al. (2004), a commonly used method to estimate causality between prices is the Granger causality test. It provides information on which direction, if any, price transmission is

\footnotetext{
${ }^{8}$ Cointegration implies the theoretical notion of a long run equilibrium relationship. If two price series are cointegrated, there is a trend of co-movement in the long run given their linear relationship. In the short run, the prices may vary, as shocks in one market may not be immediately transmitted to other markets or due to transportation delays, however, arbitration prospects confirm that these deviations from the long run equilibrium relationship are temporary" (Rapsomanikis et al., 2004, p. 58).
} 
occurring between two series. If two markets were integrated, the price in one market would generally Granger-cause the price in the other market and vice versa. Two price series may deviate from one another because of factors such as transaction costs and yet Granger causality may exist since some price signals may be transmitted from one market to the other. However, lack of Granger causality may not indicate an absence of transmission since price signals may be transmitted immediately under special conditions. Causality tests commonly use post-market integration estimation, as in the following studies: Blank and Schmiesing, 1988; Baulch, 2008; Nazlioglu, 2011; Beag and Singla, 2014.

\section{Data and Methodology}

\section{Data}

Our research contributes to the literature by using a unique data set, the Agriculture Management Information System (AMIS) ${ }^{9}$, that has daily price information of crops for the years 2010-17. This research will bridge the gap in literature by carrying out the following analysis using time-series economic modeling on the crop subsector including cereals (rice), fruits (mango and citrus) and vegetables (onion and potato): 1) checking for market integration through horizontal and vertical price transmission; that is, firstly whether price signals are being transmitted between production centers, and secondly whether price signals are being transferred from the consumer center to the producers and vice versa, respectively, using daily price data; and 2) understanding market efficiency, mainly by analyzing the speed at which horizontal and vertical price transmission takes places among the markets for the above mentioned crops.

The Agriculture Management Information System (AMIS) data set provides district-wise daily wholesale market price information. However, since AMIS reports price data only for districts in Punjab, the analysis unfortunately has to be restricted to this one province. Restricting the analysis to Punjab does not invalidate our results since agricultural marketing is a provincial subject and Punjab accounts for over 75 percent of Pakistan's production of 4 out of the 5 selected crops

\footnotetext{
${ }^{9}$ http://amis.pk/
} 
(see table 1) and 53 percent of Pakistan's population, i.e., 110 million out of 208 million (Pakistan Bureau of Statistics ${ }^{10}$, 2018). But it needs to be noted that the conclusions with regards to integration of agriculture markets of this analysis may not be fully applicable to rest of Pakistan, particularly as both agriculture markets and transport infrastructure in the Punjab are more developed than in the other the three provinces.

Table 1: Provincial Shares in Total Pakistan Production (000' tonnes) for 2016-2017

\begin{tabular}{lcccccc}
\hline Crop & Punjab Sindh Baluchistan & $\begin{array}{c}\text { Khyber } \\
\text { Pakhtunkhwa }\end{array}$ & Pakistan & $\begin{array}{c}\text { Punjab's \% } \\
\text { share in Total } \\
\text { Production }\end{array}$ \\
\hline Potato & 3660 & 6 & 22 & 143 & 3831 & 96 \\
Onion & 370 & 748 & 532 & 184 & 1833 & 20 \\
Mango & 1375 & 405 & 1 & 3 & 1784 & 77 \\
Citrus & 2117 & 26 & 7 & 30 & 2180 & 97 \\
Basmati & 2524 & 78 & 95 & 42 & 2739 & 92 \\
Rice & & & & & & \\
\hline
\end{tabular}

Source: Agricultural Statistics of Pakistan 2017-18 (2019), Ministry of National Food Security \& Research Islamabad.

In the analysis, we look at crops in three categories of agricultural produce: cereals (rice), fruits (kinnow ${ }^{11}$ and mangos) and vegetables (onions and potatoes). These items are selected because these are important crops in each category, both with regards to the country's agricultural production and exports (Ministry of National Food Security and Research, 2019a) and the regularity of data reported in the AMIS system. Even though wheat is the most important crop in Pakistan, it has not been included in our analysis because the government intervenes in the wheat market through a minimum support price (MSP) policy, which would bias any analysis of the market price data. ${ }^{12}$

\footnotetext{
${ }^{10} \mathrm{http}: / / \mathrm{www} . p b s . g o v . p k /$ content/provisional-summary-results-6th-population-and-housing-census2017-0

${ }^{11}$ Kinnow which is similar to a mandarin orange is the dominant form of citrus gown in Pakistan

${ }^{12}$ Under the support price program, the government usually announces a MSP in November, procures a substantial share of the output during the harvest period (April to June) and releases it to the flour mills during the lean season (December to March).
} 
The daily prices of products are available for an 8-year period from 2010 to $2017^{13}$. The data provides market price values for weekdays only and the reported prices of rice, mangos, onions and potatoes are per $100 \mathrm{~kg}$ while those for kinnow are per 100 pieces. For the purpose of analysis the main consumer district for all crops is taken as Lahore, which in 2017 had a population of over 11 million, i.e., 27.5 percent of Punjab's urban population, while five districts with the highest production of the selected crops in the Punjab (for the year 2016-2017) are chosen as the producer districts for that crop $^{14}$. Some limitations of the data are: i) price data is not available for all the selected districts and, ii) price data is available primarily for the months in the harvest period but there are still missing values for some days within the harvest period. The harvest period for purposes of analysis is taken as: basmati rice, September-October; kinnow, January-March; mango, JulyAugust; potatoes, January-February, April-May, August and October; onions, May-June, August and November-December (Pakistan Bureau of Statistics, 2016). Missing values, up to a maximum of two days, have been replaced with an average of the previous two days.

\section{Methodology}

The two dimensions of price transmission that will be discussed for each crop are vertical and horizontal (or spatial) price transmission. While discussing vertical transmission, we will try to understand the linkage between the prices in the main consumer market and the largest producer markets (up to a maximum of five) for each crop. For horizontal price transmission, the extent of integration that exists within the producer markets will be discussed. Price changes in the producer markets selected for each crop are analyzed to see whether there is any visible direction of transmission of price signals among the producers. In the discussion, the selected producer markets are considered as clusters if they are spatially close to each other.

Each crop is analyzed as follows. We conduct Granger causality tests to see the causality of the relationship that exists between market

\footnotetext{
${ }^{13}$ Data for mango, rice, potatoes and onions is from 2010-2017, while in the case of kinnow price data for 2014 is unavailable.

${ }^{14}$ If price data is not available for a particular district, the district with the next largest production of that crop in the Punjab is selected. However, for selection of producer districts a minimum 5 percent of Punjab's production of the crop rule is applied, and as a result for some crops there may be fewer than 5 districts included in the analysis.
} 
prices in both horizontal and vertical frameworks. In order to carry out the Granger causality tests, the following steps have to be executed. Each market is checked for its order of integration using the Augmented DickeyFuller (ADF) test for each series of prices. ADF tests the null hypothesis that a unit root exists and if this is rejected, the series is said to be stationary (Elliott et al., 1996). In the case that the pair of series (both while examining vertical and horizontal price transmission) are found to be Integrated of order $0, \mathrm{I}(0)$, we conclude that the series are not cointegrated and use a VAR framework to check for size and speed of the price adjustment among markets (Rapsomanikis et al., 2004). We then test for Granger causality within a VAR framework to assess vertical and horizontal price transmission. If the market pairs are integrated at order 1, I(1), they may be cointegrated and several tests are conducted to check for that ${ }^{15}$. Once the cointegration of markets has been determined, the series are tested for Granger causality. If the series are cointegrated, a VECM is usually estimated, and if they are not cointegrated, a VAR model is estimated and then checked for Granger causality. Cointegration itself cannot be used to make conclusions about the direction of causation between prices therefore causality tests are necessary (Ibid, 2004). Since there are missing values in our data, a VECM model could not be estimated. Therefore, only a VAR model is run to estimate the integration among markets.

\section{Results}

In this section, the discussion of each of the five selected crops is organized as follows: first, we discuss the nature of the crop, i.e., production, shelf life/storage, importance of exports or imports, etc.; second, we analyze the horizontal (spatial) price transmission among producer districts; and finally we look at the vertical price transmission between consumer and the producer markets.

\footnotetext{
15“The Johansen test is used to assess the pair-wise co-integration rank of producer-consumer markets. The cointegrating rank ( $\mathrm{r}$ ) is determined based on acceptance/rejection of null and alternative hypotheses. Next, cointegration is tested using the Two-Way Engle Granger Approach. This involves testing the cointegration of two markets based on the fact that deviations from equilibrium condition of two non-stationary variables should be stationary. This implies that, while price series may wander extensively, pairs should not diverge from one another in the long-run" (Rapsomanikis, 2004, p. 59).
} 


\section{Potato}

Potato is an important and expanding vegetable crop in Pakistan with an area and production of 178 thousand hectares and 3,831 thousand tons, respectively, in 2016 (Ministry of National Food Security and Research, 2019). Punjab province is the leading potato producer with a total production of3,660thousand tons (i.e., 96 percent of Pakistan's total production) followed by Khyber Pakhtunkhwa at 143 thousand tons, Baluchistan at 22 thousand tons and Sindh at 6 thousand tons (Table 2). Potato has three crops namely autumn (September-February), summer (March-October) and spring (January-May), with the three contributing 70-75 percent, 15-20 percent and 7-10 percent of the total production respectively (Trade Development Authority of Pakistan, 2010). The main potato producing districts in Punjab are Okara, Sahiwal, Kasur, Pakpattan and Chiniot ${ }^{16}$ (see Table 2).

Table 2: Potatoes: Area, Production and Share by Major Producer Districts (2016-2017)

\begin{tabular}{lccc}
\hline District & $\begin{array}{c}\text { Area } \\
\text { (in 000 hectares) }\end{array}$ & $\begin{array}{c}\text { Production } \\
\text { (in 000 tons) }\end{array}$ & $\begin{array}{r}\text { \% Share of } \\
\text { Punjab's Production }\end{array}$ \\
\hline Okara & 54.1 & 1269.7 & 34.7 \\
Sahiwal & 25.0 & 522.7 & 14.3 \\
Kasur & 19.3 & 429.2 & 11.7 \\
Pakpattan & 18.6 & 417.6 & 11.4 \\
Chiniot & 9.4 & 196.5 & 5.4 \\
Punjab & 166.4 & 3660.5 & 100 \\
\hline
\end{tabular}

Sources: Directorate of Agriculture, Crop Reporting Services, 2018 and Ministry of National Food Security \& Research, 2019.

In Punjab, potatoes are primarily produced for sale in urban markets and it can be safely stored up to 6 months (Arain, n.d.). The autumn crop, in addition to feeding the instant market, is placed in cold storage. The stored potatoes are gradually released during the lean crop periods generally from June onward. Pakistan is an exporter of potatoes and about 12 percent of the production is exported, with Afghanistan, UAE and Sri Lanka being the main markets (See Table 3).

${ }^{16}$ Chiniot is not included in the analysis because of non-availability of price data. 
Table 3: Exports of Potatoes from Pakistan

\begin{tabular}{lccc}
\hline $\begin{array}{l}\text { Annual } \\
\text { Average }\end{array}$ & $\begin{array}{c}\text { Partner } \\
\text { Country }\end{array}$ & $\begin{array}{c}\text { Quantity } \\
\text { (000' tons) }\end{array}$ & $\begin{array}{c}\text { Trade Value } \\
\text { (million US \$) }\end{array}$ \\
\hline $2015-2017$ & Afghanistan & 166 & 50 \\
$2015-2017$ & Sri Lanka & 71 & 12 \\
$2015-2017$ & United Arab Emirates & 94 & 14 \\
$2015-2017$ & World & 426 & 94 \\
\hline
\end{tabular}

Source: UN Comtrade database, 2015-2017.

\section{Horizontal Price Transmission in the Potato Market}

To measure horizontal price transmission in the potato market, we look at the relationship between the prices in the producer markets. It is likely that horizontal price transmission occurs through transfer of information rather than actual movement of the product between the producer districts. Three of the four largest producers (Okara, Sahiwal and Pakpattan) are relatively close to each other ${ }^{17}$, and this cluster contributes over 60 percent of the total production of potatoes in Punjab. The Granger causality results show that the largest producer, Okara, causes a change in price in the other two producer districts in the cluster, implying horizontal price transmission occurs in this direction (Table 4). The other two districts in the cluster, Sahiwal and Pakpattan, have a bidirectional relationship with each other. As far as Kasur is concerned, Sahiwal and Pakpattan have a unidirectional relationship with it and the two districts cause a change in price in Kasur. However, there doesn't seem to be any horizontal price transmission taking place between Okara and Kasur. But as Kasur is more or less a suburb of Lahore, vertical transmission between the largest producer (Okara) and the main consumer market (Lahore) may be muddling the horizontal relationship between Okara and Kasur.

\footnotetext{
${ }^{17}$ Okara is at a distance of about $60 \mathrm{~km}$ and $40 \mathrm{~km}$ from Pakpattan and Sahiwal, respectively, while Pakpattan is about $45 \mathrm{~km}$ from Sahiwal.
} 


\section{Table 4: VAR Descriptive Statistics - Potato Granger Causality Tests-} Horizontal Transmission

Dependent Variable in Regression

\begin{tabular}{|c|c|c|c|c|}
\hline $\begin{array}{l}\text { (1) } \\
\text { Regressor }\end{array}$ & $\begin{array}{c}\text { (2) } \\
\text { Okara }\end{array}$ & $\begin{array}{c}\text { (3) } \\
\text { Sahiwal }\end{array}$ & $\begin{array}{c}\text { (4) } \\
\text { Kasur }\end{array}$ & $\begin{array}{c}\text { (5) } \\
\text { Pakpattan }\end{array}$ \\
\hline Okara & - & 0.067 & 0.349 & 0.077 \\
\hline Sahiwal & 0.171 & - & 0.000 & 0.000 \\
\hline Kasur & 0.147 & 0.500 & - & 0.101 \\
\hline Pakpattan & 0.829 & 0.000 & 0.000 & - \\
\hline
\end{tabular}

Source: Author's calculations using AMIS data set 2010-2017.

Note 1: The table shows results from Granger-causality statistics that examine whether lagged values of one variable help to predict another variable. Column 1 shows the regressor while columns 2-5 show the dependent variables. The results were computed from a VAR model with an average of three lags and a constant term over the 2010-2017 sample period.

Note 2: The entries in the columns show the p-values for F-tests. P value is a measure of significance and it is significant at $10 \%$ if $\mathrm{Q}<0.1$.

As far as the speed of adjustment in prices under horizontal transmission is concerned, prices in Pakpattan adjust to prices in Okara within two days while prices in Sahiwal adjust to prices in Okara within four days. The two smaller producers in the cluster (Pakpattan and Sahiwal) are well integrated among themselves as the adjustments take place within a day in both directions. Pakpattan and Sahiwal are also well integrated with Kasur as price adjustments are taking place within a day (see Table 5). 
Table 5: Vector Auto Regression Model Results for Price Adjustment in the Potato Market- Horizontal Price Transmission

(1)

\begin{tabular}{lccccc}
\multirow{2}{*}{ Regressor } & $\begin{array}{c}\text { Day of } \\
\text { Adjustment }\end{array}$ & \multicolumn{4}{c}{ Dependent Variable } \\
\cline { 2 - 6 } & 1 & Okara & Sahiwal & Kasur & Pakpattan \\
\hline \multirow{3}{*}{ Okara } & 2 & - & -0.097 & $0.098^{\mathrm{a}}$ & 0.208 \\
& 3 & - & 0.147 & - & $0.344^{* * \mathrm{~b}}$ \\
Sahiwal & 4 & - & -0.015 & - & - \\
Pakpattan & 1 & - & $0.436^{* * *}$ & - & - \\
Kasur & 1 & 0.009 & - & $0.196^{* * *}$ & $0.243^{* * *}$ \\
\hline
\end{tabular}

Source: Author's calculations using AMIS data set 2010-2017.

a: For presentation purposes, one lag was selected (according to AIC criteria) for regression of (Okara- Kasur) therefore only day 1 adjustment coefficient is reported.

b:For presentation purposes, two lags were selected (according to AIC criteria) for regression of (Okara-Pakpattan) therefore only day 1 and day 2 adjustment coefficients are reported.

Note 1: The table shows the results from the Vector autoregressive model. It shows the speed at which the vertical and horizontal price adjustments take place. The results were computed from a VAR model with a minimum of one lag and a constant term over the 2010-2017 sample period. Column 1 shows the regressor, Column 2 shows the day of adjustment and column 3 shows the dependent variables.

Note 2: The entries in the columns show the coefficients. The number of * against each coefficient shows the significance using the $\mathrm{p}$ values. That is * representing significance of $\mathrm{p}$ value at $10 \%{ }^{* *}$ representing significance of $\mathrm{p}$ value at $5 \%$ and ${ }^{* * *}$ representing significance of $p$ value at $1 \%$.

\section{Vertical Price Transmission in the Potato Market}

To examine vertical price transmission in the potato market, we look at the relationship between the prices in the consumer market (Lahore) and the producer markets. Vertical transmission is a result of both a transfer of information and the commodity (potatoes). The price of potatoes in Lahore determines the price in the largest producer market Okara as well as the other producers. While the consumer market drives prices in the largest producer market, there exists a bidirectional relationship between Lahore and the other three producers - Sahiwal, Pakpattan and Kasur, which implies that these producer markets also drive the prices in the consumer market (See Table 6). 


\section{Table 6: VAR Descriptive Statistics-Potato Granger Causality Tests- Vertical Transmission \\ Dependent Variable in Regression}

\begin{tabular}{|c|c|c|c|c|c|}
\hline $\begin{array}{l}\text { Regressor } \\
\text { (1) }\end{array}$ & $\begin{array}{c}\text { (2) } \\
\text { Lahore }\end{array}$ & $\begin{array}{c}(3) \\
\text { Okara }\end{array}$ & $\begin{array}{c}(4) \\
\text { Sahiwal }\end{array}$ & $\begin{array}{c}(5) \\
\text { Kasur }\end{array}$ & $\begin{array}{c}\text { (6) } \\
\text { Pakpattan }\end{array}$ \\
\hline Lahore & - & 0.008 & 0.000 & 0.000 & 0.000 \\
\hline Okara & 0.967 & & & & \\
\hline Sahiwal & 0.003 & & & & \\
\hline Kasur & 0.028 & & & & \\
\hline Pakpattan & 0.000 & & & & \\
\hline
\end{tabular}

Source: Author's calculations using AMIS data set 2010-2017.

Note 1: The table shows results from Granger-causality statistics that examine whether lagged values of one variable help to predict another variable. Column 1 shows the regressor while the columns 2-6 show the dependent variables. The results were computed from a VAR model with an average of two lags and a constant term over the 2010-2017 sample period.

Note 2: The entries in the columns show the p-values for F-tests. P value is a measure of significance and it is significant at $10 \%$ if $\mathrm{Q}<0.1$.

Looking at vertical adjustment of prices, prices in Okara, Sahiwal, Pakpattan and Kasur adjust to prices in Lahore within a day. Even though Sahiwal, Pakpattan and Kasur prices adjust in both directions with Lahore, the adjustment is relatively small, i.e. less than 10 percent. The size of the coefficients implies that 20-30 percent of the adjustment takes place within a day from Lahore to the producer markets (except for Kasur) thereby implying that this channel is dominant in transmitting the price signals (Table 7). In a study conducted in Ethiopia using monthly price data, potato producer markets were adjusting to consumer market prices within 3.5 months and bidirectional causality was also observed (Tadesse, 2016). 

Table 7: Vector Auto Regression Model Results for Price Adjustment in
the Potato Market- Vertical Price Transmission

(1)

Regressor
(2)

Day of

Adjustment
(3)

Dependent Variable

\begin{tabular}{lccccc}
\hline Lahore & & Okara & Sahiwal & Kasur & Pakpattan \\
& 1 & $0.213^{* * *}$ & $0.245^{* * *}$ & $0.143^{* * *}$ & $0.303^{* *}$ \\
\hline Okara & 1 & Lahore & & & \\
Sahiwal & 1 & 0.059 & & & \\
Kasur & 1 & $0.054^{* *}$ & & & \\
Pakpattan & 1 & $0.074^{* * * *}$ & & & \\
\hline
\end{tabular}

Source: Author's calculations using AMIS data set 2010-2017.

Note 1: The table shows the results from the Vector autoregressive model. It shows the speed at which the vertical and horizontal price adjustments take place. The results were computed from a VAR model with a minimum of one lag and a constant term over the 2010-2017 sample period. Column 1 shows the regressor, Column 2 shows the day of adjustment and column 3 shows the dependent variables.

Note 2: The entries in the columns show the coefficients. The number of * against each coefficient shows the significance using the $p$ values. That is * represents significance of $p$ value at $10 \%,{ }^{* *}$ represents significance of $p$ value at $5 \%$ and ${ }^{* * *}$ represents significance of $\mathrm{p}$ value at $1 \%$.

To sum up, it is seen that the potato market is connected both vertically and horizontally. Generally, most adjustment in the prices between markets takes place within a day of the change taking place in the other markets. Therefore, we can say that the potato market in the Punjab is well integrated and adjustments are rapid.

\section{Onion}

The total area and production of onions was 340 thousand hectares and 1833 thousand tons, respectively, in 2016 (Ministry of National Food Security and Research, 2019). Sindh province is the leading onion producer with a total production of 748 thousand tons followed by Baluchistan at 532 thousand tons, Punjab at 370 thousand tons and Khyber Pakhtunkhwa at 184 thousand tons (Table 1). In other words, only 20 percent of onions are produced in the Punjab, and since it has over 50 percent of Pakistan's population, probably a major part of the onions sold in its consumer markets, such as Lahore, comes from Sindh 
and Baluchistan, which produce 40 and 30 percent, respectively, of the country's output. The main onion producing districts in Punjab are Khanewal, Rajanpur, Rahim Yar Khan and Bahawalpur ${ }^{18}$ (Table 8).

Table 8: Onions: Area, Production and Share by Major Producer Districts (2016-2017)

\begin{tabular}{lccc}
\hline District & $\begin{array}{c}\text { Area (in 000 } \\
\text { hectares) }\end{array}$ & $\begin{array}{c}\text { Production (in } \\
\text { 000 tons) }\end{array}$ & $\begin{array}{c}\text { \% Share of } \\
\text { Punjab's } \\
\text { Production }\end{array}$ \\
\hline Khanewal & 6.4 & 50.1 & 13.5 \\
Rajanpur & 1.7 & 35.5 & 9.6 \\
Rahim Yar Khan & 3.1 & 34.6 & 9.3 \\
Bahawalpur & 3.0 & 24.2 & 6.5 \\
Punjab & 42.8 & 370.4 & 100.0 \\
\hline
\end{tabular}

Sources: Directorate of Agriculture, Crop Reporting Services, 2018 and Ministry of National Food Security \& Research, 2019.

The agro-ecological diversity in the country enables onions to be produced almost year-round. Due to limited shelf life and absence of cold storage facilities in the country, onions cannot be kept for an extended period of time and have to be sold in the domestic or international markets soon after the time of harvest (Agriculture Market Information Service, 2004). Therefore, Pakistan both exports and imports onions each year, with the two quantities being about the same, i.e., equivalent to about 6 percent of its production. Exports are primarily to UAE, Malaysia and Afghanistan while imports are almost entirely from Afghanistan and China (See Table 9). Imports from Afghanistan probably largely supply Khyber Pakhtunkhwa and the northern /central districts of Punjab, including Lahore.

\footnotetext{
${ }^{18}$ No other district in the Punjab produces as much as 5 percent of Punjab's output therefore only 4 producer districts are included in the horizontal (spatial) price transmission analysis.
} 
Table 9: Export of Onions from Pakistan

\begin{tabular}{lccc}
\hline Annual & Partner & Quantity & Trade Value \\
\hline Average & Country & $\mathbf{( 0 0 0 '}$ tons) & (million US \$) \\
\hline $2015-2017$ & United Arab Emirates & 34 & 6.3 \\
$2015-2017$ & Afghanistan & 13 & 5 \\
$2015-2017$ & Malaysia & 33 & 7.2 \\
$2015-2017$ & World & 121 & 27.5 \\
\hline \multicolumn{4}{c}{ Import of Onions from Pakistan } \\
\hline $2015-2017$ & Afghanistan & 77 & 13.7 \\
$2015-2017$ & China & 38 & 70.8 \\
\hline
\end{tabular}

Source: UN Comtrade database, 2015-2017.

\section{Horizontal Price Transmission in the Onion Market}

To measure horizontal price transmission in the onion market, we look at the relationship between the prices in the producer markets. The selected producer districts. i.e., Khanewal, Rajanpur, Rahim Yar Khan, Bahawalpur and Lodhran are all in southern Punjab and lie along the road links from Sindh/Baluchistan to Lahore. The Granger causality results show a bidirectional relation between all producers. This shows that horizontal price transmission occurs well across all the producer districts, implying that each producer causes a change in price in the other producer within the southern Punjab cluster (see Table 10). 


\section{Table 10: VAR Descriptive Statistics- Onion Granger Causality Tests-} Horizontal Price Transmission

Dependent Variable in Regression

\begin{tabular}{lcccc}
\hline Regressor & $\mathbf{( 2 )}$ & $\mathbf{( 3 )}$ & $\mathbf{( 4 )}$ & $\mathbf{( 5 )}$ \\
$\mathbf{( 1 )}$ & Khanewal & Rajanpur & Rahim Yar Khan & \begin{tabular}{c} 
Bahawalpur \\
\hline Khanewal
\end{tabular} \\
Rajanpur & - & $\mathbf{0}$ & $\mathbf{0 . 0 0 2}$ & $\mathbf{0}$ \\
Rahim Yar Khan & $\mathbf{0}$ & - & $\mathbf{0}$ & 0.627 \\
Bahawalpur & $\mathbf{0}$ & $\mathbf{0 . 0 0 6}$ & - & $\mathbf{0}$ \\
\hline
\end{tabular}

Source: Author's calculations using AMIS data set 2010-2017.

Note 1: The table shows results from Granger-causality statistics that examine whether lagged values of one variable help to predict another variable. Column 1 shows the regressor while the remaining (2-6) show the dependent variables. The results were computed from a VAR model with an average of three lags and a constant term over the 2010-2017 sample period.

Note 2: The entries in the columns show the p-values for F-tests. P value is a measure of significance and it is significant at $10 \%$ if $\mathrm{Q}<0.1$.

As far as the adjustment period in prices under horizontal transmission is concerned, one-day adjustments are found among all markets. This implies that markets are well integrated, as rapid transmission of price information among all producer markets is found. Khanewal being the largest producer also efficiently adjusts to prices of other smaller producers and vice versa (see Table 11). 


\section{Table 11: Vector Auto Regression Model Results for Price Adjustment in the Onion Market- Horizontal Price Transmission}

(1)

Regressor
(2)

Day of Adjustment
(3)

\begin{tabular}{lccccc}
\hline & \multicolumn{5}{c}{ Khanewal RajanPur Rahim Yar Khan Bahawalpur } \\
\hline Khanewal & 1 & - & $0.185^{* * *}$ & $0.185^{* * *}$ & $0.166^{* * *}$ \\
RajanPur & 1 & $0.279^{* * *}$ & - & $0.229^{* * *}$ & $0.261^{* * *}$ \\
Rahim Yar Khan & 1 & $0.406^{* * *}$ & $0.129^{* *}$ & - & $0.190^{* * *}$ \\
Bahawalpur & 1 & $0.279^{* * *}$ & 0.044 & $0.119^{*}$ & - \\
\hline
\end{tabular}

Source: Author's calculations using AMIS data set 2010-2017.

Note 1: The table shows the results from the Vector autoregressive model. It shows the speed at which the vertical and horizontal price adjustments take place. The results were computed from a VAR model with a minimum of one lag and a constant term over the 2010-2017 sample period. Column 1 shows the regressor, Column 2 shows the day of adjustment and column 3 shows the dependent variables.

Note 2: The entries in the columns show the coefficients. The number of ${ }^{*}$ against each coefficient shows the significance using the $p$ values. That is * represents significance of $p$ value at $10 \%,{ }^{* *}$ represents significance of $p$ value at $5 \%$ and ${ }^{* * *}$ represents significance of $\mathrm{p}$ value at $1 \%$.

\section{Vertical Price Transmission in the Onion Market}

To examine vertical price transmission in the onion market, we look at the relationship between the prices in the consumer market (Lahore) and the producer markets. Vertical transmission is a result of both a transfer of information and the commodity (onion). The results show that the price of onions in Lahore determines the price in all producer markets and, at the same time, all producers (except Bahawalpur) determine the price in the Lahore. This means all producers are well connected with the consumer market and vice versa (see Table 12). 


\section{Table 12: VAR Descriptive Statistics- Onion Granger Causality Tests-} Vertical Price Transmission

Dependent Variable in Regression

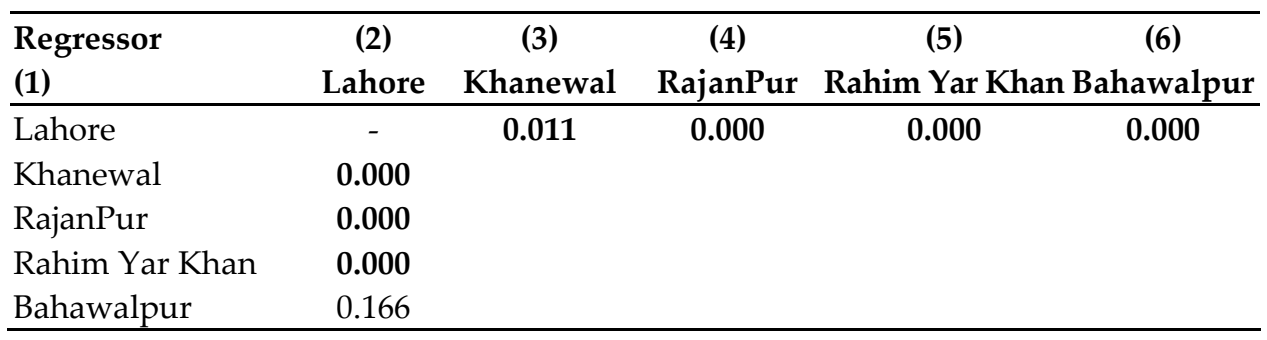

Source: Author's calculations using AMIS data set 2010-2017.

Note 1: The table shows results from Granger-causality statistics that examine whether lagged values of one variable help to predict another variable. Column 1 shows the regressor while the remaining (2-7) show the dependent variables. The results were computed from a VAR model with an average of three lags and a constant term over the 2010-2017 sample period.

Note 2: The entries in the columns show the p-values for F-tests. P value is a measure of significance and it is significant at $10 \%$ if $\mathrm{Q}<0.1$.

The onion market is well connected as adjustment in the prices among markets takes place within a day of the change that takes place in price. The onion market is therefore is well integrated and adjustments are rapid. Within a day, the price in Lahore (the consumer market) adjusts to prices in a producer market and vice versa. However, the size of the coefficient in most districts (with exception of Rahim Yar Khan and Bahawalpur) shows a larger effect (of 50-70 percent of the adjustment) in the direction of producer markets impacting the consumer market. This implies a supply driven effect showing that the price is set in the producer market and that in turn determines the price in the consumer market the next day (See Table 13). 


\section{Table 13: Vector Auto Regression Model Results for Price Adjustment in the Onion Market- Vertical Price Transmission}

(1)

Regressor
(2)

Day of

Adjustment
(3)

Dependent Variable

\begin{tabular}{|c|c|c|c|c|c|}
\hline & & Khanewal & Rajanpur & Rahim Yar K & Bahawalpur \\
\hline \multirow[t]{2}{*}{ Lahore } & 1 & $0.064^{* *}$ & $0.044^{* *}$ & $0.303^{* * *}$ & $0.296^{* * *}$ \\
\hline & & Lahore & & & \\
\hline Khanewal & 1 & $0.549^{* * *}$ & & & \\
\hline RajanPur & 1 & $0.705^{* * *}$ & & & \\
\hline Rahim Yar Khan & 1 & $0.166^{* * *}$ & & & \\
\hline Bahawalpur & 1 & -0.03 & & & \\
\hline Bahawalpur & 2 & $0.142^{* *}$ & & & \\
\hline
\end{tabular}

Source: Author's calculations using AMIS data set 2010-2017.

Note 1: The table shows the results from the Vector autoregressive model. It shows the speed at which the vertical and horizontal price adjustments take place. The results were computed from a VAR model with a minimum of one lag and a constant term over the 2010-2017 sample period. Column 1 shows the regressor, Column 2 shows the day of adjustment and column 3 shows the dependent variables.

Note 2: The entries in the columns show the coefficients. The number of * against each coefficient shows the significance using the $p$ values. That is * represents significance of $p$ value at $10 \%{ }^{* *}$ represents significance of $p$ value at $5 \%$ and ${ }^{* * *}$ represents significance of $\mathrm{p}$ value at $1 \%$.

To sum up, it is seen that the onion market is also well connected both vertically and horizontally. Generally, most adjustment in the prices between markets takes place within a day of the change taking place in the other markets. Therefore, we can say that the onion market in the Punjab is well integrated and adjustments are rapid.

\section{Mango}

The total area and production of mangos was 419 thousand hectares and 1784 thousand tons, respectively, in 2016 (Ministry of National Food Security and Research, 2019). Mango is the second largest fruit produced in Pakistan after citrus. Punjab produces 77 percent of Pakistan's total mango output, while the rest is largely produced in Sindh (Table 2). More than 200 varieties of mangoes are cultivated in Pakistan. Sindhri (primarily in Sindh) and Chaunsa (primarily in the Punjab) are the most famous varieties in the country (Javed et.al, 2012). Because of its 
dominance among the varieties in the Punjab and the non-availability of data for other varieties our analysis is based on the Chaunsa variety. The main mango producing districts in Punjab are Multan, Rahim Yar Khan, Khanewal and Muzaffargarh ${ }^{19}$. Area, production and percentage of Punjab's output produced in each district can be seen in Table 14.

\section{Table 14: Mango: Area, Production and Share by Major Producer Districts (2016-2017)}

\begin{tabular}{lccc}
\hline District & $\begin{array}{c}\text { Area (in 000 } \\
\text { hectares) }\end{array}$ & $\begin{array}{c}\text { Production (in } \\
\text { 000 tons) }\end{array}$ & $\begin{array}{c}\text { \% share of } \\
\text { Punjab's } \\
\text { Production }\end{array}$ \\
\hline Multan & 31 & 420 & 31 \\
Rahim Yar Khan & 24 & 310 & 23 \\
Khanewal & 14 & 180 & 13 \\
Muzaffargarh & 19 & 269 & 7 \\
Punjab & 106 & 1,375 & 100 \\
\hline
\end{tabular}

Sources: Directorate of Agriculture, Crop Reporting Services, 2018 and Ministry of National Food Security \& Research, 2019.

Mangoes have a extremely short shelf life, which is measured in days rather than in weeks and this has implications for the direction of vertical price transmission. Also, as mangoes are highly perishable, they are exported by air (Baloch et.al, 2011). Pakistan has a very weak system for managing the cool chain for effective transportation of fresh mangoes from producers to the airports as well for meeting the international phytosanitary standards for export of fresh fruits and therefore less than 5 percent of the mango crop is exported. Pakistan mainly exports mangoes to United Arab Emirates, United Kingdom and Saudi Arabia (See Table 15).

\footnotetext{
${ }^{19}$ As price data is not available for Muzaffargarh, it is not included in the analysis. Also as no other district in the Punjab produces as much as 5 percent of Punjab's output, only 3 producer districts are included in the horizontal (spatial) price transmission analysis.
} 
Table 15: Exports of Mango Crop from Pakistan

\begin{tabular}{lccc}
\hline $\begin{array}{l}\text { Annual } \\
\text { Average }\end{array}$ & $\begin{array}{c}\text { Partner } \\
\text { Country }\end{array}$ & $\begin{array}{c}\text { Quantity } \\
\text { (000' tonnes) }\end{array}$ & $\begin{array}{c}\text { Trade Value } \\
\text { (US \$) }\end{array}$ \\
\hline $2015-2017$ & United Arab Emirates & 26 & 19.3 \\
$2015-2017$ & United Kingdom & 7 & 9.9 \\
$2015-2017$ & Saudi Arabia & 4 & 5.1 \\
2015-2017 & World & 54 & 51.0 \\
\hline
\end{tabular}

Source: UN Comtrade database, 2015-2017.

\section{Horizontal Price Transmission in the Mango Market}

To measure horizontal price transmission in the mango market, we look at the relationship between the prices in the producer markets. Horizontal transmission occurs by means of a transfer of information. In the mango market, the large producers are all in southern Punjab with two of them being fairly close to each other (Multan and Khanewal), together contributing 44 percent of total production in Punjab. The largest producer Multan causes a change in the price of Rahim Yar Khan whereas Khanewal causes a change in price in Multan. Khanewal and Rahim Yar Khan Granger-cause changes in price within their markets, implying a bi-directional relationship (see Table 16).

\section{Table 16: VAR Descriptive Statistics - MangoGranger Causality Tests- Horizontal Transmission}

Dependent Variable in Regression

(1)

(2)

(3)

(4)

\begin{tabular}{lccc} 
Regressor & Multan & Rahim Yar Khan & Khanewal \\
\hline Multan & - & $\mathbf{0 . 0 3 0}$ & 0.505 \\
Rahim Yar Khan & 0.227 & - & $\mathbf{0 . 0 0 2}$ \\
Khanewal & $\mathbf{0 . 0 8 4}$ & $\mathbf{0 . 0 0 0}$ & - \\
\hline
\end{tabular}

Source: Author's calculations using AMIS data set 2010-2017.

Note 1: The table shows results from Granger-causality statistics that examine whether lagged values of one variable help to predict another variable. Column 1 shows the regressor while the remaining (2-4) show the dependent variables. The results were computed from a VAR model with an average of three lags and a constant term over the 2010-2017-sample period.

Note 2: The entries in the columns show the p-values for F-tests. P value is a measure of significance and it is significant at $10 \%$ if $\mathrm{Q}<0.1$. 
As far as the time period of adjustment in prices under horizontal transmission is concerned, prices in Rahim Yar Khan adjust to prices in Multan within 3 days while Khanewal causes a change in price in Multan within 2 days. Khanewal and Rahim Yar Khan both adjust to each other's prices. However, the mechanism is such that Multan causes a change in price in Rahim Yar Khan, and Khanewal causes a change in price in both Multan and Rahim Yar Khan (See Table 17). Despite being a smaller producer, Khanewal plays a more central role in horizontal transmission of prices. A possible explanation maybe that Khanewal, as one of new settlements at time when the British developed the canal colonies in the Punjab, has always been agriculturally the most progressive district in Southern Punjab and probably seen as the trend-setter by other districts in the region.

\section{Table 17: Vector Auto Regression Model Results for Price Adjustment in the Mango Market- Horizontal Price Transmission}

(1)

\section{Regressor}

(2)

Day of

Adjustment
(3)

Dependent Variable

\begin{tabular}{lcccc}
\hline & & Multan & Rahim Yar Khan & Khanewal \\
\hline Multan & 1 & - & -0.027 & 0.087 \\
& 2 & - & 0.112 & 0.075 \\
\multirow{2}{*}{ Rahim Yar Khan } & 3 & - & $0.210^{* *}$ & - \\
& 1 & 0.034 & - & -0.038 \\
\multirow{4}{*}{ Khanewal } & 2 & -0.008 & - & 0.0699 \\
& 3 & 0.006 & - & $0.107^{*}$ \\
& 1 & -0.043 & $0.104^{*}$ & - \\
\hline
\end{tabular}

Source: Author's calculations using AMIS data set 2010-2017.

Note 1: The table shows the results from the Vector autoregressive model. It shows the speed at which the vertical and horizontal price adjustments take place. The results were computed from a VAR model with a minimum of one lag and a constant term over the 2010-2017. Column 1 shows the regressor, Column 2 shows the day of adjustment and column 3 shows the dependent variables.

Note 2: The entries in the columns show the coefficients. The number of * against each coefficient shows the significance using the $p$ values. That is * represents significance of $p$ value at $10 \%,{ }^{* *}$ represents significance of $p$ value at $5 \%$ and ${ }^{* * *}$ represents significance of $\mathrm{p}$ value at $1 \%$. 


\section{Vertical Price Transmission in the Mango Market}

To examine vertical price transmission in the mango market, we look at the relationship between the prices in the consumer market (Lahore) and the producer markets. Vertical transmission is a result of both a transfer of information and the commodity (mango). Granger causality tests help shows a unidirectional relationship between Lahore and Multan where the price of mangoes in Lahore determines the price in the largest producer market, Multan. The fixed supply of mangoes at any time and their short-shelf life means that the largest producer (Multan) has to be the price taker. Khanewal being virtually a suburb of Multan, which is also a big city, has the option to ship the mangoes either to Lahore or Multan. Thus, the decision by Khanewal producers whether to sell in Lahore or Multan has an impact on the prices in the former. As a result, in the case of Khanewal, the direction of the price signal seems to be from the producer to the consumer market ${ }^{20}$. The relationship between Lahore and Rahim Yar Khan (which is the $2^{\text {nd }}$ largest producer in the Punjab) is bidirectional. The reason for this maybe that the distance between Lahore and Rahim Yar Khan is almost $600 \mathrm{~km}$, i.e., about the same as its distance from Karachi (population over 15 million) in Sindh and therefore producers in Rahim Yar Khan could choose whether to send mangoes to Lahore or Karachi based on the prices in the two cities and their decision in turn would impact on the prices of mangoes in the two cities (See Table 18).

${ }^{20}$ It is also likely that, as discussed for horizontal transmission, Khanewal's position as a price setter for Lahore is because of its central role in Southern Punjab. 


\section{Table 18: VAR Descriptive Statistics- Mango Granger Causality Tests- Vertical Price Transmission}

Dependent Variable in Regression

(1)

\begin{tabular}{lcccc} 
Regressor & Lahore & Multan & Rahim Yar Khan & Khanewal \\
\hline Lahore & & $\mathbf{0 . 0 3 6}$ & $\mathbf{0 . 0 1 6}$ & 0.488 \\
Multan & $\mathbf{0 . 1 0 4}$ & & & \\
Rahim Yar Khan & $\mathbf{0 . 0 0 1}$ & & & \\
Khanewal & $\mathbf{0 . 0 1 2}$ & & & \\
\hline
\end{tabular}

Source: Author's calculations using AMIS data set 2010-2017.

Note 1: The table shows results from Granger-causality statistics that examine whether lagged values of one variable help to predict another variable. Column 1 shows the regressor while the remaining (2-5) show the dependent variables. The results were computed from a VAR model with an average of three lags and a constant term over the 2010-2017 sample period.

Note 2: The entries in the columns show the p-values for F-tests. P value is a measure of significance and it is significant at $10 \%$ if $\mathrm{Q}<0.1$.

When looking at adjustment of prices between consumer and producer markets, prices in Lahore determine prices in Multan and vice versa, after three days. However, the size of the coefficient shows that the dominant transmission channel is also an adjustment in prices from the producer to the consumer market. The relationship between Lahore and Rahim Yar Khan is significant in both directions within 5 days; however, the size of coefficient shows that the dominant transmission channel is an adjustment in prices from the consumer to the producer market. Khanewal, on the other hand, has the most rapid adjustment mechanism and prices in Lahore adjust to prices in Khanewal within a day (see Table 19). In India, mango markets are found to be well integrated where adjustments take place within a month of the change that takes place in prices (Pardhi, 2016). 


\section{Table 19: Vector Auto Regression Model Results for Price Adjustment in the Mango Market- Vertical Price Transmission}

(1)

(2)

(3)

\begin{tabular}{|c|c|c|c|c|}
\hline \multirow{2}{*}{$\begin{array}{l}\text { Regressor } \\
\text { Lahore }\end{array}$} & \multirow[t]{2}{*}{ Day of Adjustment } & \multicolumn{3}{|c|}{ Dependent Variable } \\
\hline & & Multan & Rahim Yar Khan & Khanewal \\
\hline & 1 & -0.044 & 0.054 & 0.097 \\
\hline & 2 & -0.067 & 0.054 & 0.012 \\
\hline & 3 & $0.087^{*}$ & -0.014 & -0.061 \\
\hline & 4 & 0.04 & -0.124 & 0.006 \\
\hline & 5 & & $0.117^{*}$ & -0.0001 \\
\hline \multicolumn{5}{|c|}{ Lahore } \\
\hline \multirow[t]{3}{*}{ Multan } & 1 & 0.075 & & \\
\hline & 2 & 0.053 & & \\
\hline & 3 & $0.173^{* *}$ & & \\
\hline \multirow[t]{5}{*}{ Rahim Yar Khan } & 1 & 0.767 & & \\
\hline & 2 & 0.005 & & \\
\hline & 3 & 0.007 & & \\
\hline & 4 & -0.052 & & \\
\hline & 5 & $0.093^{* *}$ & & \\
\hline Khanewal & 1 & $0.010^{* *}$ & & \\
\hline
\end{tabular}

Source: Author's calculations using AMIS data set 2010-2017.

Note 1: The table shows the results from the Vector autoregressive model. It shows the speed at which the vertical and horizontal price adjustments take place. The results were computed from a VAR model with a minimum of one lag and a constant term over the 2010-2017 sample period. Column 1 shows the regressor, Column 2 shows the day of adjustment and column 3 shows the dependent variables.

Note 2: The entries in the columns show the coefficients. The number of * against each coefficient shows the significance using the $\mathrm{p}$ values. The ${ }^{*}$ represents significance of $\mathrm{p}$ value at $10 \%,{ }^{* *}$ represents significance of $p$ value at $5 \%$ and ${ }^{* * *}$ represents significance of $\mathrm{p}$ value at $1 \%$.

\section{Kinnow}

Kinnow (mandarin) is one of the most important fruit crops in Pakistan with a total area and production of 206 thousand hectares and 2180 thousand tons, respectively, in 2016 (Ministry of National Food Security and Research, 2019). Citrus is almost entirely grown in the Punjab with 97 percent of total production occurring in this province (Table 2). The peak kinnow harvesting months are January to March. The main kinnow producing districts in Punjab are Sargodha, Toba Tek 
Singh $^{21}$, Mandi Bahauddin, and Khanewal. Area, production and percentage produced in each district can be seen in Table 20.

Table 20: Kinnow: Area, Production and Share by Major Producer Districts (2016-2017)

\begin{tabular}{lccc}
\hline District & $\begin{array}{c}\text { Area } \\
\text { (in 000 } \\
\text { hectares) }\end{array}$ & $\begin{array}{c}\text { Production } \\
\text { (in 000 tons) }\end{array}$ & $\begin{array}{c}\text { \% Share of } \\
\text { Punjab's } \\
\text { Production }\end{array}$ \\
\hline Sargodha & 83 & 1,077 & 56 \\
Toba Tek Singh & 12 & 215 & 11 \\
Mandi Bahauddin & 9 & 116 & 6 \\
Punjab & $\mathbf{1 5 0}$ & $\mathbf{1 9 1 7}$ & $\mathbf{1 0 0}$ \\
\hline
\end{tabular}

Sources: Directorate of Agriculture, Crop Reporting Services, 2018 and Ministry of National Food Security \& Research, 2019.

Being a non-climacteric fruit, kinnow without treatment has a low shelf life even in cold storage and may lose its quality because of some physiochemical changes (Haider et. al, 2017). In the 1990s, the adoption of a new technology, imported from Italy, for waxing of kinnow upon harvesting greatly extended its shelf-like and that initiated the era of kinnow exports for Pakistan. Currently, over 20 percent of the production is exported with main markets Afghanistan (and possibly onward to other Central Asian Countries), the Russian Federation and United Arab Emirates (see Table 21).

Table 21: Exports of Kinnow Crop from Pakistan

\begin{tabular}{lccc}
\hline Annual Average & Partner & $\begin{array}{c}\text { Quantity (000' } \\
\text { tons) }\end{array}$ & $\begin{array}{c}\text { Trade Value (US } \\
\text { \$) }\end{array}$ \\
\hline $2015-2017$ & Afghanistan & 162 & 62 \\
$2015-2017$ & Russian Federation & 85 & 45 \\
$2015-2017$ & United Arab Emirates & 46 & 17 \\
$2015-2017$ & World & 389 & 165 \\
\hline
\end{tabular}

Source: UN Comtrade database, 2015-2017.

${ }^{21}$ As price data is not available for Toba Tek Singh and Mandi Bahauddin, they could not be included in the analysis. Thus, as no other district in the Punjab produces as much as 5 percent of Punjab's output, we only one producer district, i.e. Sargodha, and therefore no horizontal (spatial) price transmission analysis is carried out. 


\section{Vertical Price Transmission in the Kinnow Market}

To examine vertical price transmission in the kinnow market, we look at the relationship between the prices in the consumer market (Lahore) and the producer market (Sargodha). Vertical transmission is a result of both a transfer of information and the commodity (kinnow). The Granger causality test shows a unidirectional relationship between producer and consumer market. The price of kinnow in Lahore determines the price of kinnow in Sargodha. The opposite channel is also significant at around 10 percent significance level implying that there is bi-directional relationship (see Table 22).

\section{Table 22: VAR Descriptive Statistics- Kinnow Granger Causality Tests- Vertical Transmission}

Dependent Variable in Regression

(1)

\begin{tabular}{lcc} 
Regressor & Lahore & Sargodha \\
\hline Lahore & - & $\mathbf{0 . 0 0 5}$ \\
Sargodha & 0.101 & - \\
\hline
\end{tabular}

Source: Author's calculations using AMIS data set 2010-2017 (excluding 2014).

Note 1: The table shows results from Granger-causality statistics that examine whether lagged values of one variable help to predict another variable. Column 1 shows the regressor while the remaining (2-5) show the dependent variables. The results were computed from a VAR model with an average of three lags and a constant term over the 2010-2017 (excluding 2014) sample period.

Note 2: The entries in the columns show the p-values for F-tests. P value is a measure of significance and it is significant at $10 \%$ if $\mathrm{Q}<0.1$.

We measured the speed of adjustment of prices between markets as three days. But the size of the coefficient shows that the adjustment of prices from the producer, Sargodha, to Lahore dominates, i.e. Sargodha is the price setter (see Table 23). The reason for this may be that the price in Sargodha is determined by demand and prices in the export markets. Also as kinnow's shelf-life is significantly extended by processing and storage, the sellers are not in a hurry to sell in the local market because the sellers know that any kinnows in storage that they are unable to export can always be sold in the local market in the off-season at a premium. 


\section{Table 23: Vector Auto Regression Model Results for Price Adjustment in the Kinnow Market- Vertical Price Transmission}

\begin{tabular}{lcc}
\hline $\mathbf{( 1 )}$ & $\mathbf{( 2 )}$ & $\mathbf{( 3 )}$ \\
Regressor & Day of Adjustment & Dependent Variable \\
\hline & & Sargodha \\
\hline Lahore & 1 & -0.002 \\
& 2 & -0.018 \\
& 3 & $0.03^{*}$ \\
\hline Sargodha & & Lahore \\
& 1 & 0.113 \\
& 2 & 0.369 \\
& 3 & $0.532^{* *}$ \\
\hline
\end{tabular}

Source: Author's calculations using AMIS data set 2010-2017 (excluding 2014).

Note 1: The table shows the results from the Vector autoregressive model. It shows the speed at which the vertical and horizontal price adjustments take place. The results were computed from a VAR model with a minimum of one lag and a constant term over the 2010-2017 (excluding 2014) sample period. Column 1 shows the regressor, Column 2 shows the day of adjustment and column 3 shows the dependent variables.

Note 2: The entries in the columns show the coefficients. The number of ${ }^{*}$ against each coefficient shows the significance using the $p$ values. $A$ * represents significance of $p$ value at $10 \%,{ }^{* *}$ represent significance of $p$ value at $5 \%$ and ${ }^{* * *}$ represent significance of $p$ value at $1 \%$.

Rice

The total area and production of rice was 4291 thousand hectares and 6849 thousand tons, respectively, in 2016 (Ministry of National Food Security and Research, 2019). Rice is grown primarily in Sindh and Punjab, with 64 percent being produced in the latter. Basmati rice is the most famous of the rice varieties grown in Pakistan and is known for its flavor and quality (Gain Report- USDA Foreign Agriculture Service, 2018). Basmati rice is harvested from September to October and Punjab produces over 90 percent of the basmati rice grown in Pakistan (Table 2). The main rice producing districts in Punjab are Sheikhupura, Hafizabad, Sialkot, Nankana Sahab, Gujranwala and Okara22. Area, production and percentage produced in each district can be seen in Table 24 .

22 Due to non-availability of price data for Sheikhupura, Hafizabad, and, Nankana Sahab, the only markets that could be considered for this analysis are Sialkot, Gujranwala, and Okara. 
Table 24: Basmati Rice: Area, Production and Share by Major Producer Districts (2016-2017)

\begin{tabular}{lccc}
\hline District & $\begin{array}{c}\text { Area } \\
\text { (in 000 hectares) }\end{array}$ & $\begin{array}{c}\text { Production } \\
\text { (in 000 tons) }\end{array}$ & $\begin{array}{c}\text { \% Share of } \\
\text { Total Production }\end{array}$ \\
\hline Sheikhupura & 158 & 290 & 11.5 \\
Hafizabad & 104 & 213 & 8.4 \\
Sialkot & 115 & 206 & 8.2 \\
Nankana Sahab & 99 & 194 & 7.7 \\
Gujranwala & 102 & 184 & 7.3 \\
Okara & 72 & 143 & 5.6 \\
Punjab & $\mathbf{1 3 5 3}$ & $\mathbf{2 5 2 4}$ & $\mathbf{1 0 0}$ \\
\hline
\end{tabular}

Sources: Directorate of Agriculture, Crop Reporting Services, 2018 and Ministry of National Food Security \& Research, 2019.

Pakistan is among top ten rice producers in the world and it exports just under 60 percent of its rice production. Basmati rice as a percentage of total rice exports from Pakistan is about 26 percent by value and about 13 percent by quantity (Rice Exporters Association of Pakistan, 2015-2017, see table 25). Farmers harvest paddy, which can only be kept for short period unless it is dried in a mill. Rice millers acquire most of the crop, dry and polish it, and then store it. Once milled, rice can be stored for more than a year. Rice millers are also the primary exporters of rice, with some of the large exporters owning many rice mills spread over the main rice growing areas. These large rice exporters also directly market basmati rice domestically under their own brand names. Most of the IRRI rice and some of the basmati rice sold in the domestic market is unbranded. 
Table 25: Export of Basmati Rice as a percentage of Total Rice in Pakistan

\begin{tabular}{lcccccc}
\hline & \multicolumn{2}{c}{ Basmati Rice } & \multicolumn{2}{c}{ Total Rice } & \multicolumn{2}{c}{$\begin{array}{c}\text { Basmati Rice } \\
\text { percentage share } \\
\text { of Total Rice }\end{array}$} \\
\hline & $\begin{array}{c}\text { Quantity } \\
(\mathbf{0 0 0}\end{array}$ & $\begin{array}{c}\text { Trade } \\
\text { Value } \\
\text { tons) }\end{array}$ & $\begin{array}{c}\text { Quantity } \\
\text { (million }\end{array}$ & $\begin{array}{c}\text { Trade } \\
\text { tons) }\end{array}$ & $\begin{array}{c}\text { Quantity } \\
\text { (million }\end{array}$ & Trade \\
& & US\$) & & US \$) & & Value \\
\hline 2015 & 503 & 455 & 4,262 & 1,860 & 11.8 & 24.5 \\
2016 & 480 & 427 & 3,585 & 1,607 & 13.4 & 26.5 \\
2017 & 501 & 525 & 4,024 & 2,000 & 12.5 & 26.2 \\
Average & 495 & 469 & 3957 & 1,823 & 12.6 & 25.7 \\
\hline
\end{tabular}

Source: Calculations based on data from the Rice Exporters Association of Pakistan, Retrieved 10 January, 2020 from http://reap.com.pk/download/index.asp

The most important export markets for Pakistan's rice are Kenya, Afghanistan, China and United Arab Emirates (see Table 26).

Table 26: Exports of Rice Crop from Pakistan

\begin{tabular}{llcc}
\hline $\begin{array}{l}\text { Annual } \\
\text { Average }\end{array}$ & \multicolumn{1}{c}{ Partner } & $\begin{array}{c}\text { Quantity (000' } \\
\text { tons) }\end{array}$ & $\begin{array}{c}\text { Trade Value } \\
\text { (million US \$) }\end{array}$ \\
\hline $2015-2017$ & Kenya & 533 & 209 \\
$2015-2017$ & United Arab Emirates & 204 & 150 \\
$2015-2017$ & China & 456 & 161 \\
$2016-2017$ & Afghanistan & 1,298 & 122 \\
$2015-2017$ & World & 3,890 & 1,791 \\
\hline
\end{tabular}

Source: UN Comtrade database, 2015-2017.

\section{Horizontal Price Transmission in the Rice Market}

To measure horizontal price transmission in the rice market, we look at the relationship between the prices in the producer markets. Surprisingly, we find no causality in any market, in any direction. This implies that the signals are not being transferred and it can be said that the price transmission mechanism is weak (see Table 27). In the basmati rice market, there are five producers together in a cluster in central Punjab (i.e., Sheikhupura, Hafizabad, Sialkot, Nankana Sahab and Gujranwala) and together they contribute 43 percent of total production 
in Punjab. Unfortunately, we have price data from only for two producers in the cluster, which does not include the top two producers, and that limits the usefulness of the analysis. But finding no connectedness between Sialkot and Gujranwala certainly indicates that horizontal price transmission is weak at best. The probable explanation is in the nature of the rice crop and market. A few rice millers in each district control the market in their area and there is a lack of price competition in the market. Also, the rice traded in the producer wholesale markets is a small proportion of total production and is largely for local consumption. Thus, we can conclude that the rice market in Punjab is fragmented and not well integrated.

Table 27: VAR Descriptive Statistics- Rice Granger Causality TestsHorizontal Transmission

Dependent Variable in Regression

\begin{tabular}{lccc}
\hline Regressor & $\mathbf{( 2 )}$ & $\mathbf{( 3 )}$ & $\mathbf{( 4 )}$ \\
$\mathbf{( 1 )}$ & Sialkot & Gujranwala & Okara \\
\hline Sialkot & - & 0.257 & 0.201 \\
Gujranwala & 0.51 & - & 0.888 \\
Okara & 0.516 & 0.663 & - \\
\hline
\end{tabular}

Source: Author's calculations using AMIS data set 2010-2017.

Note 1: The table shows results from Granger-causality statistics that examine whether lagged values of one variable help to predict another variable. Column 1 shows the regressor while the remaining (2-4) show the dependent variables. The results were computed from a VAR model with an average of three lags and a constant term over the 2010-2017-sample period.

Note 2: The entries in the columns show the p-values for F-tests. P value is a measure of significance and it is significant at $10 \%$ if $\mathrm{Q}<0.1$.

As far as the period of adjustment in prices under horizontal transmission is concerned, no adjustment of prices takes place either within the market cluster or with Okara, reinforcing the finding that the producer districts are not integrated with each other (See Table 28). 


\section{Table 28: Vector Auto Regression Model Results for Price Adjustment in the Rice Market- Horizontal Price Transmission}

\section{Regressor}

(1)
(2)

Day of Adjustment
(3)

\begin{tabular}{lcccc}
\hline & & Sialkot & Gujranwala & Okara \\
\hline Sialkot & 1 & - & 0.073 & -0.022 \\
Gujranwala & 1 & 0.062 & - & 0.021 \\
Okara & 1 & 0.082 & 0.07 & - \\
\hline
\end{tabular}

Source: Author's calculations using AMIS data set 2010-2017 (excluding 2014).

Note 1: The table shows the results from the Vector autoregressive model. It shows the speed at which the vertical and horizontal price adjustments take place. The results were computed from a VAR model with a minimum of one lag and a constant term over the 2010-2017 sample period. Column 1 shows the regressor, Column 2 shows the day of adjustment and column 3 shows the dependent variables.

Note 2: The entries in the columns show the coefficients. The number of ${ }^{*}$ against each coefficient shows the significance using the $p$ values. $A$ * represents significance of $p$ value at $10 \%,{ }^{* *}$ represent significance of $p$ value at $5 \%$ and ${ }^{* * *}$ represent significance of $p$ value at $1 \%$.

\section{Vertical Price Transmission in the Rice Market}

To examine vertical price transmission in the rice market, we look at the relationship between the prices in the consumer market (Lahore) and the producer markets. Prices in the two producer districts, Sialkot and Gujranwala, Granger-cause changes in price in the consumer market, thereby implying a supply driven effect from producers to consumers (see Table 29). 
Table 29: VAR Descriptive Statistics-Rice Granger Causality TestsVertical Price Transmission

Dependent Variable in Regression

(1)

(2)

(3)

(4)

(5)

\begin{tabular}{lcccc} 
Regressor & Lahore & Sialkot & Gujranwala & Okara \\
\hline Lahore & - & 0.477 & 0.771 & 0.498 \\
Sialkot & $\mathbf{0 . 0 0 0}$ & & & \\
Gujranwala & $\mathbf{0 . 0 0 6}$ & & & \\
Okara & 0.107 & & & \\
\hline
\end{tabular}

Source: Author's calculations using AMIS data set 2010-2017.

Note 1: The table shows results from Granger causality statistics that examine whether lagged values of one variable help to predict another variable. Column 1 shows the regressor while the remaining (2-5) show the dependent variables. The results were computed from a VAR model with an average of three lags and a constant term over the 2010-2017 sample period.

Note 2: The entries in the columns show the p-values for F-tests. P value is a measure of significance and it is significant at $10 \%$ if $\mathrm{Q}<0.1$.

The rice market is vertically well connected as the adjustment of prices from Gujranwala and Sialkot to Lahore takes place in one day (see Table 30). This, unlike the findings with regards to horizontal transmission, corresponds to the findings for Bangladesh by Dawson and Dey (2002) that the law of one price holds in the rice market in that country since the rice prices in Dhaka and each regional market were so perfectly integrated with each other that a change in price in one market was mirrored somewhere else. 


\section{Table 30: Vector Auto Regression Model Results for Price Adjustment in the Rice Market- Vertical Price Transmission}

(1)

(2)

(3)

\begin{tabular}{lcccc} 
Regressor & Day of Adjustment & \multicolumn{3}{c}{ Dependent Variable } \\
\hline & \multicolumn{5}{c}{ Sialkot } & Gujranwala & Okara \\
\hline Lahore & 1 & 0.083 & 0.033 & -0.038 \\
\hline & \multicolumn{5}{c}{} \\
\hline Sialkot & 1 & $0.171^{* * *}$ & \\
Gujranwala & 1 & $0.144^{* *}$ & \\
Okara & 1 & 0.108 & \\
\hline
\end{tabular}

Source: Author's calculations using AMIS data set 2010-2017 (excluding 2014).

Note 1: The table shows the results from the Vector autoregressive model. It shows the speed at which the vertical and horizontal price adjustments take place. The results were computed from a VAR model with a minimum of one lag and a constant term over the 2010-2017. Column 1 shows the regressor, Column 2 shows the day of adjustment and column 3 shows the dependent variables.

Note 2: The entries in the columns show the coefficients. The * against each coefficient shows the significance using the $p$ values. ${ }^{*}$ represents significance of $p$ value at $10 \%$, ${ }^{* *}$ represents significance of $p$ value at $5 \%$ and ${ }^{* * *}$ represents significance of $p$ value at $1 \%$.

\section{Summary of Findings}

We have found that potato, onion and mango markets are well integrated both horizontally and vertically, with the speed of adjustment generally (with the exception of mango) being very rapid (see Table 31). Therefore, we can say that these three markets are technically efficient. However, based on the results it is difficult to say whether kinnow and basmati rice markets are technically efficient. The reasons for this are two-fold.

One, in the case of both the crops a large part of the output is exported and, therefore, it is likely that international prices of these crops play a major role in determining the local price. But since we do not have data on the daily international prices of these crops we are unable to examine the extent of their integration with the world market. However, as there are no government restrictions on their export, we expect that the local producer markets are probably well integrated with the world and regional markets. 
Two, for both the crops there are limitations with regards to availability of price data for the producer markets. In the case of kinnow, we have data for only one producer market and, therefore, it is not possible to examine extent of horizontal integration. In the case of basmati rice we do not have price data for the two largest producer markets. Therefore, the result that the basmati rice market is not integrated horizontally and price signals are not transmitted among producer markets is subject to the caveat that for other crops, the larger producer markets generally play a central role in horizontal transmission, and data on these is missing in the case of rice.

As far as vertical integration is concerned, both markets seem to be fairly well integrated. Therefore, it is likely that the markets for these two crops are also technically efficient, but we cannot categorically say so based on our data. With regards to efficiency of the markets, an interesting finding is that in 40 out of the 44 relationships that have significant causality ${ }^{23}$, the adjustment in prices takes place within one day. This rapid adjustment is probably because of widespread use of mobile phones and the resulting real-time communication of price information from one market to another. In other words, the introduction of new communication technologies in the last two decades has probably played an important role in improving the technical efficiency of agricultural markets in the Punjab, and possibly other developing countries.

\footnotetext{
${ }^{23}$ There are 33 market-pairs for horizontal and vertical transmission combined. As we are looking at adjustment in both directions we have a total of 66 possible results. In the case of Basmati Rice for horizontal transmission we find no significant relationship among the 3 market pairs. Out of the remaining 30 market pairs, in 16 the relationship is unidirectional and in 14 it is bidirectional, i.e. a total of 44 relationships with significant causality.
} 
Table 31: Summary of Results

\begin{tabular}{|c|c|c|c|c|c|}
\hline \multirow{4}{*}{ Crop } & \multicolumn{5}{|c|}{ Horizontal Transmission } \\
\hline & \multirow{2}{*}{\multicolumn{2}{|c|}{$\begin{array}{c}\text { Degree of Integration } \\
\text { (as indicated by) }\end{array}$}} & \multirow{2}{*}{\multicolumn{2}{|c|}{$\begin{array}{c}\text { Degree of Adjustment } \\
\text { (as indicated by) }\end{array}$}} & \multirow{3}{*}{$\begin{array}{l}\text { If Any Market Plays A } \\
\text { Central Role }\end{array}$} \\
\hline & & & & & \\
\hline & Direction* & $\begin{array}{l}\% \text { of markets } \\
\text { connected }^{* *}\end{array}$ & $\begin{array}{c}\text { Speed of } \\
\text { Adjustment }+\end{array}$ & $\begin{array}{l}\text { Coefficient of } \\
\text { Adjustment++ }\end{array}$ & \\
\hline Potato & Unidirectional & Medium & Rapid & Medium & Okara \\
\hline Onion & Bidirectional & Strong & Rapid & Medium & Khanewal \\
\hline Mango & Bidirectional & Strong & Medium & Weak & Khanewal \\
\hline \multirow[t]{2}{*}{ Rice } & N.A. & N.A. & N.A. & N.A. & N.A. \\
\hline & \multicolumn{5}{|c|}{ Vertical Transmission } \\
\hline \multirow{3}{*}{ Crop } & \multicolumn{2}{|c|}{ Degree of Integration } & \multicolumn{2}{|c|}{ Degree of Adjustment } & Market(s) Playing a \\
\hline & \multicolumn{2}{|c|}{ (as indicated by) } & \multicolumn{2}{|c|}{ (as indicated by) } & $\begin{array}{c}\text { Central or Dominating } \\
\text { Role }\end{array}$ \\
\hline & Direction* & $\begin{array}{l}\% \text { of markets } \\
\text { connected }^{* *}\end{array}$ & $\begin{array}{c}\text { Speed of } \\
\text { Adjustment+ }\end{array}$ & $\begin{array}{l}\text { Coefficient of } \\
\text { Adjustment++ }\end{array}$ & \\
\hline Potato & Bidirectional & Strong & Rapid & Medium & Consumer (Lahore) \\
\hline Onion & Bidirectional & Strong & Rapid & Strong & Producers \\
\hline Mango & Bidirectional & Strong & Slow & Weak & Producers \\
\hline Kinnow & Unidirectional & N.A. & Medium & Weak & Producer (Sargodha) \\
\hline Rice & Unidirectional & Weak & Rapid & Medium & Producers \\
\hline
\end{tabular}

*Direction is explained through granger causality tests. If $\mathrm{p}$ value is significant in both directions, we say it is bidirectional and if it is significant in one direction we say it is unidirectional.

** This is determined by looking at what percentage of the total market-pairs in granger causality tests are significant. If $\%<40 \%$ then Weak, if $40 \%$ to $60 \%$ then Medium, and if $>60 \%$ then Strong

+ If the significant adjustment coefficient is 1 day then Rapid, if 2-3 days then Medium, and if 4 days then Slow

++ This is determined by looking at the coefficient of the VAR model. Only day 1 significant coefficient sizes are compared. If the significance occurs on a day later than day 1 , it is considered as a weak. If the size of the coefficients (i.e. \% of price adjustment taking place on day one) for at least $50 \%$ of the sample is $<10 \%$, then weak, if $10-20 \%$ then Medium, and if $>20 \%$ then Strong.

Source: Authors' calculations.

Another finding of our analysis is that in most cases (potato being the exception) it is the producer markets that determine the price in the consumer market. This is not surprising, because in the case of agricultural products, in the very short run, we can expect market prices to be supply driven. What is interesting is that this is not the case for potatoes, where the price in the producer markets is determined by the consumer market.

The explanation probably lies in the nature of the different crops: In the case of onions and mangoes, because of the short shelf-life, the fact that 
producer markets determine the price in the consumer markets is not a reflection of producers' market-power, but the result of the harvest size more or less simultaneously determining prices in both producer and consumer markets. In the case of kinnow and basmati rice, because of the longer shelflife and the outside option of the export market, it is an indicator of the producers' market-power as the sellers probably decide how much to sell in the local market on any given day, based on the international prices and projected demand. Finally, potatoes are somewhere in-between in the sense that because of the use of cold-storage they have a longer shelf-life but storage is costly and export options are few, therefore, while producers have some market power but it is limited - i.e. daily prices in the producer markets are responsive to prices in the consumer market.

\section{A Reality Check}

As a test of the medium-term impact of technical efficiency of agriculture markets in Pakistan we look at changes in cropping patterns to see if these are in line with the changes in market demand and government price interventions. An important determinant of demand for agricultural products in a country is income levels and distribution: according to the World Bank (2016) "[i]n Pakistan, the reduction in poverty led to an increase in dietary diversity for all income groups. For the poorest, the share of expenditure devoted to milk and milk products, chicken, eggs and fish rose, as did the share devoted to vegetables and fruits. In contrast, the share of cereals and pulses, which provide the cheapest calories, declined steadily between FY02 and FY14" ${ }^{24}$ Thus, if markets are efficient in transmitting price signals, the changing pattern of demand should impact cropping patterns in the medium term. ${ }^{25}$.

Trends in cropping patterns for the period 2000 to 2014 are presented in Table 32. It is seen that the share of the area under vegetables and fruits increased by over 30 percent during this period, while that of pulses declined by over 10 percent. Also, during this period, the share of area under maize, which is the main ingredient in animal feed, particularly in the poultry industry, increased by 8 percent and, because of the rapid adoption of hybrid seeds, its production increased by 130 percent (Agriculture Statistics of

\footnotetext{
${ }^{24}$ Pakistan Development Update: Making growth matter, World Bank, November 2016, pages 34-35.

${ }^{25}$ Ignoring international trade for the moment.
} 
Pakistan, 2016-17). ${ }^{26}$ Thus the changing pattern of demand has had a strong impact on the cropping pattern.

However, contrary to what we expected, the share of the area under wheat, the main cereal consumed in Pakistan, increased by about 5 percent during this period. The reason probably was that the Peoples Party Government (2008-2013) significantly increased the support price of wheat and since then subsidies have been provided for exporting the surpluses wheat exports increased from 0.5 million tons per annum (1.8 percent of the output) in 2000-2004 to 1.0 million tons per annum (3.9 percent of the output) in 2010-201427. The share of area under rice, the other important cereal crop, also increased during this period, but rice is a major export crop and its exports more than doubled from on average 1.6 million tons per annum (6.9 percent of the output) in 2000-2004 to 3.6 million tons per annum (12 percent of the output) in 2010-201428.

In brief, medium-term trends in cropping patterns in the post2000 period were in accordance with the changing pattern of domestic (and international) demand, except in the case of wheat where the effect of government interventions dominates. This supports the results of our analysis that agricultural markets in the Punjab (and probably in Pakistan) are well integrated and price signals are transmitted efficiently between markets.

\footnotetext{
${ }^{26}$ In the period 2000-2004 to 2010-2014 maize yields increased by a phenomenal 120 percent, which may be compared with increases in wheat and rice yields of 17 percent and 19 percent respectively during this period.

${ }^{27} \mathrm{https} / / / \mathrm{www}$.indexmundi.com/agriculture/?country=pk\&commodity=wheat\&graph=exports

${ }^{28} \mathrm{https}: / / \mathrm{www}$. indexmundi.com/agriculture/?country=pk\&commodity=milled-rice\&graph=exports
} 
Table 32: Trends in Cropping Pattern in Pakistan's Agriculture - 2000 to 2014

(Average \% share of the total cropped)

\begin{tabular}{lccc}
\hline Crops & $\mathbf{2 0 0 0 - 2 0 0 4}$ & $\mathbf{2 0 0 5 - 2 0 0 9}$ & $\mathbf{2 0 1 0 - 2 0 1 4}$ \\
\hline Wheat & 36.67 & 36.60 & 38.80 \\
Cotton & 13.26 & 13.00 & 12.46 \\
Rice & 10.47 & 11.24 & 11.24 \\
Maize & 4.24 & 4.38 & 4.56 \\
Sugarcane & 4.61 & 4.40 & 4.41 \\
Pulses & 6.27 & 6.27 & 5.55 \\
Vegetables \& Fruits & 4.72 & 6.12 & 6.31 \\
Oilseeds & 2.64 & 3.17 & 2.81 \\
Fodder & 11.19 & 10.34 & 9.49 \\
Other crops & 5.94 & 4.48 & 4.36 \\
\hline
\end{tabular}

Source: Author's calculations using, Agriculture Statistics of Pakistan 2017-18, 2019, Ministry of National Food Security and Research. http://www.mnfsr.gov.pk/pubDetails.aspx

\section{Conclusion}

For the development of a dynamic agriculture sector, efficiency of agriculture markets is critical. We posited that market efficiency is best thought of as having two elements, i.e. technical efficiency which is measured by the extent of integration of agricultural markets and economic efficiency for which marketing margins on aggregate, i.e. the percentage difference in the price paid by the consumers and that received by the farmers are the appropriate measure. We know that economic efficiency of agricultural markets in the Punjab is probably quite low because agricultural produce passes through many different hands before reaching the consumer and marketing margins at each point in the chain are high; but, due to the lack of any data on farm gate prices we are unable to test for it. Therefore, the focus of our research has been on determining the technical efficiency of the agricultural marketing system in the Punjab.

The concepts of market integration and price transmission, where market integration describes the extent to which different markets are connected to one another, have been used in many studies to measure market efficiency - which we call technical efficiency. To determine the extent of market integration we used the Agriculture Management Information System (AMIS) dataset that has daily wholesale market 
prices for most crops in the Punjab for the years 2010-2017. As we had argued that non-traditional crops are more likely to be adversely affected by an outdated agricultural marketing system we selected four vegetable and fruit crops (potato, onion, mango, kinnow) and one cereal (basmati rice $^{29}$ ) for analysis.

To test for strength and speed of price transmission between agricultural markets, Granger causality tests and Vector Auto Regressive (VAR) models were used. We found that potato, onion and mango markets are well integrated both horizontally and vertically, with the speed of price adjustment in most cases (mango is the exception) being very rapid. Therefore, we can say that these three markets are technically efficient. It is difficult, however, to categorically say that kinnow and basmati rice markets are technically efficient, because although both markets are vertically fairly well integrated we are unable to satisfactorily measure the extent of horizontal integration as price data were not available for a number of important producer markets. Also, as a reality check, we looked at trends in the cropping pattern over the period 2000 to 2014 and found that they are in line with the changing market demand and government price interventions.

In conclusion, we want to highlight that market integration (or what we call technical efficiency) is not sufficient for "producers and consumers [to] realize their potential gains" as has been argued by some researchers (Reddy, 2012, Varela et al., 2012) and what we call economic efficiency, is a necessary condition for these gains to be fully realized. More research is needed in the area of economic efficiency of agriculture markets, and in the case of Pakistan such research would be timely because the Punjab Agriculture Marketing Regulatory Authority (PAMRA) Act 2020 has fundamentally reformed the legal and regulatory framework for agricultural marketing in the Punjab and such a study could provide a baseline for measuring the economic impact of the legal reforms.

${ }^{29}$ It would have been preferable to have included wheat as the cereal crop but, because of extensive government intervention in the market, meaningful analysis of the wheat market was not possible. 


\section{References}

Agriculture Marketing Information Service, Directorate of Agriculture. (2004). Marketing of onion, problem and prospects. Retrieved November 20, 2019, from http://www.amis.pk/pdf/Pulications/ Onion\%20Report.pdf

Ahsan, M. (2018). Commissions and omissions: Agricultural producer markets in Pakistan. Policy and Institutional Reforms to Improve Horticultural Markets in Pakistan (Working Paper No. 01/18). Retrieved October 7, 2019, from https://www.monash.edu/_data/ assets/pdf_file/0010/1428769/WP1_Rana_complete.pdf

Arain, G. (n.d.). Potato cultivation in Pakistan. Retrieved April 10, 2019, from http://www.valleyirrigationpakistan.com/wp-content/uploads /2012/09/Potato-Cultivation-in-Pakistan.pdf

Baffes, J. (1991). Some further evidence on the law of one price: The law of one price still holds. American Journal of Agricultural Economics, 73(4), 1264-1273. doi:10.2307/1242454

Bakus, Z., Ferto, I., and Falkowski, J. (2013). What causes asymmetric price transmission in agro-food sector? Meta-analysis perspective. Discussion paper. Institute of Economics, Research Centre for Economic and Regional Studies, Hungarian Academy of Sciences

Baloch, M. K., Bibi, F., and Jilani, M. S. (2011). Quality and shelf life of mango (Mangiferaindica L.) fruit: As affected by cooling at harvest time. Scientia Horticulturae,130(3), 642-646. doi:10.1016/j. scienta.2011.08.022

Barrett, C. B., \& Li, J. R. (2002). Distinguishing between equilibrium and integration in spatial price analysis. American Journal of Agricultural Economics, 84(2), 292-307. doi:10.1111/1467-8276.00298

Basmati Rice the True Pride of Pakistan. (n.d.). Retrieved January, 2020, from https://reap.com.pk/index.php 
Baulch, B. (1997). Testing for food market integration revisited. Journal of Development Studies,33(4), 512-534. https://doi.org/10.1080/ 00220389708422479

Baulch, B., Hansen, H., Trung, L., and Tam, T. (2008). The spatial integration of paddy markets in Vietnam. Journal of Agricultural Economics,59(2), 271-295. https://doi.org/10.1111/j.1477-9552.2007. 00148.x

Beag, F., and Singla, N. (2014). Cointegration, causality and impulse response analysis in major apple markets of India. Agricultural Economics Research Review, 27(2), 289. https://doi.org/10.5958/09740279.2014.00032.9

Blank, S., and Schmiesing, B. (1988). Modeling of agricultural markets and prices using causality and path analysis. North Central Journal of Agricultural Economics, 10(1), 35. https://doi.org/10.2307/1349234

Dawson, P. J., and Dey, P. K. (2002). Testing for the law of one price: Rice market integration in Bangladesh. Journal of International Development, 14(4), 473-484. doi:10.1002/jid.888

Directorate of Agriculture, Crop Reporting Services. (2017). Kharif Crop Final Estimates Data Book 2016-17. Retrieved March 9, 2018, from https://crsagri7.pitb.gov.pk/system/files/BOOK\%20RABI\%20FINA L\%202016-17.pdf\#overlay-context=reports

Elliott, G., Rothenberg, T. J., and Stock, J. H. (1996). Efficient tests for an autoregressive unit root. Econometrica, 64(4), 813-836. doi:10.2307/2171846

Gardner, B. L., and Brooks, K. M. (1994). Food prices and market integration in Russia: 1992-93. American Journal of Agricultural Economics,76(3), 641-646. doi:10.2307/1243681

Goletti, F., Ahmed, R., and Farid, N. (2007). Structural determinants of market integration: the case of rice markets in Bangladesh. The Developing Economies, 33(2), 196-198. https://doi.org/10.1111/j.17461049.1995.tb00713.x 
Goodwin, B. (2006). Spatial and vertical price transmission in meat markets. Presentation, University of Kentucky, North Carolina.

Ghosh, M. (2003). Spatial integration of wheat markets in India: Evidence from cointegration tests. Oxford Development Studies, 31(2), 159171. doi:10.1080/13600810307426

Haider, S.-A. T.-A., Ahmad, S., Khan, A. S., and Basra, S. M. A. (2017). Comparison of different fruit coatings to enhance the shelf life of kinnow mandarin. Pakistan Journal of Agricultural Sciences,54(01), 35-44. doi:10.21162/pakjas/17.5317

International Labor Organization (2019). Employment in agriculture (\% of total employment). Retrieved May 1, 2020, from https://data.worldbank.org/indicator/SL.AGR.EMPL.ZS

Jena, P. K. (2016). Commodity market integration and price transmission: Empirical evidence from India. Theoretical and Applied Economics,23(3), 283-306.

Kaabia, B., Gill, M., Maria, J., and Boshnjaku, L. (2002). Price transmission asymmetries in the Spanish lamb sector. Presentation. $X^{\text {th }}$ EAAE Congress, Spain. doi:10.22004/ag.econ.24908

KC, G., and Rajalaxmi, A. (2019). Spatial price integration and price transition in major markets of onion in India. Journal of Pharmacognosy and Phytochemistry,2, 1058-1063.

Khan, M. A., and Khan, S. L. (2010). Potential markets of potato. Trade Development Authority of Pakistan. Retrieved 11 January, 2020, from https://www.tdap.gov.pk/doc_reports/tdap_report_on_ potential_markets_of_potatoes.pdf

Kharin, S., Lajdova, Z., and Bielik, P. (2017). Price transmission on the Slovak dairy market. Studies in Agricultural Economics, 119(3), 148155. doi:10.7896/j.1711

Kinnucan, H. W., and Forker, O. D. (1987). Asymmetry in farm - retail price transmission for major dairy products. American Journal of Agricultural Economics, 69(2), 285-292. doi:10.2307/1242278 
Listorti, G., and Esposti, R. (2016). Horizontal price transmission in agricultural markets: Fundamental concepts and open empirical issues. Bio-Based and Applied Economics, 1(1), 81-96.

Li, G., and Janssen, W. (2020). Modernizing Punjab's farming to benefit farmers and consumers. Retrieved June, 2020, from https://blogs.worldbank.org/endpovertyinsouthasia/modernizingpunjabs-farming-benefit-farmers-and-consumers

Maitra, S. (2019). Time series analysis using Granger's causality and VAR model: An example with python code. Medium Towards Data Science. Retrieved 4 May 2020, from https://towardsdatascience.com/ granger-causality-and-vector-auto-regressive-model-for-time-seriesforecasting-3226a64889a6.

Makama, S. A., and Amruthat, T. J. (2016). Spatial market integration of rice between India and Nigeria: A co-integration approach. Journal of Agriculture and Veterinary Science, 9(4), 1-7.

Ministry of Finance. (1980-2016). Pakistan Economic Survey. Retrieved February 23, 2018, from http://www.finance.gov.pk/rebuttals1. html

Ministry of National Food Security and Research. (2019A). Fruit, vegetables and condiments statistics of Pakistan 2017-18. Retrieved June 24, 2019, from http://www.mnfsr.gov.pk/frmDetails.aspx

Ministry of National Food Security and Research. (2019). Agricultural statistics of Pakistan 2017-18. Retrieved December 20, 2019, from http://www.mnfsr.gov.pk/frmDetails.aspx

Nazlioglu, S. (2011). World Oil and agricultural commodity prices: Evidence from nonlinear causality. Energy Policy, 39(5), 2935-2943. https://doi.org/10.1016/j.enpol.2011.03.001

Nisbet, R., Elder, J., and Miner, G. (2009). Chapter 4 - Data Understanding and Preparation. In Handbook of Statistical analysis and data mining applications. 49-75. doi: https://doi.org/10.1016/B978-0-12-3747655.00004-8 
Ozturk, O. (2020). Market integration and spatial price transmission in grain markets of Turkey. Applied Economics, 52(18), 1936-1948. https://doi.org/10.1080/00036846.2020.1726862

Pakistan Bureau of Statistics. (2016). Crop calendar for potatoes and onions. Retrieved March 15, 2018, from http://www.pbs.gov.pk/sites/ default/files//tables/Table-14 Crop_Potato \& Onion Calendar.pdf

Pakistan Bureau of Statistics. (2018). District wise census results census 2017. Retrieved December 15, 2019, from http://www.pbs.gov.pk/sites/ default/files//tables/Table-14 Crop_Potato \& Onion Calendar.pdf

Parsley, D., and Wei, S.-J. (1996). Convergence to the law of one price without trade barriers or currency fluctuations. The Quarterly Journal of Economics, 111(4), 1211-1236. doi:10.3386/w5654

Pardhi, R. M. (2016). Market integration and price forecasting of mango: An empirical analysis. Ph.D. Thesis, Department of Agricultural Economics, Institute of Agricultural Sciences, Banaras Hindu University, Varanasi.

Paul, R.K., Saxena, R., Chaurasia, S., Zeeshan, M., and Rana, S. (2015). Examining export volatility, structural breaks in price volatility and linkages between domestic and export prices of onion in India. Agricultural Economics Research Review, 28 (conf.), 101-116. doi:10.5958/0974-0279.2015.00026.9

Paul, U.K., Das, G., Debnath, A., and Mathur, T. (2016). Market integration and price leadership in India's onion market. Review of Market Integration, 8(1-2), 49-64. doi:10.1177/0974929216687881

Ramadas, S., Chandrasekaran, S., P, V., and Thomas, L. (2014). Testing market integration and convergence to the law of one price in Indian onions. African Journal of Agricultural Research, 9(40), 29752984. https://doi.org/10.5897/ajar2013.8037

Rapsomanikis, G., Hallam, D., and Conforti, P. (2004). Market integration and price transmission in selected food and cash crop markets of developing countries: Review and applications. Commodity Market Review, 51-75. 
Ravallion, M. (1986). Testing market integration. American Journal of Agricultural Economics, 68(1), 102-109. doi:10.2307/1241654

Reddy, A. (2011). Market integration of grain legumes in India: The case of the chickpea market. SAARC Journal of Agriculture, 10(2), 11-29. doi:10.3329/sja.v10i2.18320

Shahzad, M. A., Razzaq, A., and Qing, P. (2019). On the wheat support policy in Pakistan. Journal of Economic Impact, 1(3), 80-86.

Tadesse, M. (2016). Transaction costs and spatial integration of vegetable and fruit market in Ethiopia. Ethiopian Journal of Economics, 24(1).

The World Bank. (2016). Pakistan development update- making growth matter. Retrieved May 15, 2020, from http://documents.worldbank.org/ curated/en/935241478612633044/pdf/109961-WP-PUBLIC-disclosed11-9-16-5-pm-Pakistan-Development-Update-Fall-2016-withcompressed-pics.pdf

The Punjab agricultural marketing regulatory authority (amendment) ordinance. (2019). Retrieved October 7, 2019, from http://www.amis.pk/Laws/Ordinance/PAMRA.pdf

Usman, M., and Haile, M. (2017). Producer to retailer price transmission in cereal markets of Ethiopia. Food Security,9(4), 815-829. https://doi.org/10.1007/s12571-017-0692-0

United States Department of Agriculture. (n.d.). Pakistan milled rice exports by year. Retrieved June, 20, from https://www.indexmundi.com/ agriculture/?country=pk\&commodity=milled-rice\&graph=exports

United States Department of Agriculture. (n.d.). Pakistan wheat exports by year. Retrieved June, 20, from https://www.indexmundi.com/ agriculture/?country $=$ pk\&commodity $=$ wheat\&graph $=$ exports

Varela, G., Carroll, E., and Iacovone, L. (2013). Determinants of market integration and price transmission in Indonesia. ASEAN Economic Bulletin, 30(1), 19. https://doi.org/10.1355/ae30-1b 
Wohlgenant, M. (2001). Chapter 16 marketing margins: Empirical analysis. Handbook of Agricultural Economics, 1, 933-970. doi:10.1016/s1574-0072(01)01007-6

World Development Indicators: The World Bank. (2020, April). Retrieved May 1, 2020, from http://wdi.worldbank.org/table/4.2

The World Bank. (2016, November). Pakistan development update. 34-35. Retrieved April 28, 2020, from http://documents.worldbank.org/ curated/en/935241478612633044/pdf/109961-WP-PUBLICdisclosed-11-9-16-5-pm-Pakistan-Development-Update-Fall-2016with-compressed-pics.pdf

UN Comtrade. International Trade Statistics Database. (n.d.). Retrieved October 10, 2019, from https://comtrade.un.org/

United States Department of Agriculture. (2018). Global agricultural information network (GAIN). Foreign Agriculture Service. Retrieved 20 April, 2020, from https://www.fas.usda.gov/databases/globalagricultural-information-network-gain

Yang, J., Bessler, D. A., and Leatham, D. J. (2015). The law of one price: Developed and developing country market integration. Journal of Agricultural and Applied Economics. Retrieved October 28, 2019, from https://www.cambridge.org/core/journals/journal-of-agriculturaland-applied-economics/article/div-classtitlethe-law-of-one-pricedeveloped-and-developing-country-market-integrationdiv/ CE8FC05322063F13AC605137592831D2

Yazgan, E., and Yilmazkuda, H. (2011). Price-level convergence: New evidence from U.S. Cities. Economics Letters, 110 (2),76-78

Zahid, M., Qayyum, A., and Malik, W. (2007). Dynamics of wheat market integration in northern Punjab, Pakistan. The Pakistan Development Review, 46(4II), 817-830. https://doi.org/10.30541/v46i4ii 